\title{
ABOUT THE FIRST APPEARANCE OF THE EARLY SARMATIANS IN THE LOWER DON REGION
}

\author{
Vyacheslav P. Glebov \\ OOO Archaeological Research Bureau, Rostov-on-Don, Russian Federation \\ Anton V. Dedyulkin \\ Southern Federal University, Rostov-on-Don, Russian Federation
}

\begin{abstract}
There are different points of view regarding the date of the appearance of the early Sarmatian archaeological culture of the $2^{\text {nd }}-1^{\text {st }}$ centuries BC within the Lower Don region. However, most researches have been of the view that the Lower Don region and the Northeastern Black Sea region were developed by the Sarmatians relatively late, namely not earlier than the second half of the $2^{\text {nd }}$ century BC. The main objective of this study is to define the date of the first appearance of the Sarmatians on the territory of the Don region based on the analysis of the archaeological data from Sarmatian and ancient archeology, as well as information from the literary and epigraphic sources. According to the scale of the relative chronology there is plenty of early monuments in the Sarmatian antiquities within the $2^{\text {nd }}$ century BC. However, the number of chronological indicators in Sarmatian burials of this time horizon is relatively low. On the basis of the Rhodian amphora with stamps, black-glazed cantharoi and Megarian bowls, the date of the earliest complexes can be set within the second or third quarters of the $2^{\text {nd }}$ century BC. The arrival of the Sarmatians had a general destabilizing effect on the situation in the Don region and the Northeastern Black Sea region. The destruction of settlements and the devastation of territories were recorded on the Bosporus. The city of Tanais in the Lower Don region was fortified in the second quarter of the $2^{\text {nd }}$ century BC. The first reliable mentions of the Sarmatians in official documents are dated to the end of the first - the beginning of the second quarter of the $2^{\text {nd }}$ century BC (the treaty is dated $179 \mathrm{BC}$, Delphic manumissions). Further the authors conclude that the first appearance of the Sarmatians in the Lower Don region and the Northeastern Black Sea region is associated with the movement of nomadic tribes as a result of the expansion of the Xiongnu state, formed at the end of the $3^{\text {rd }}$ century BC, which reached the Russian southern steppes as a result of domino effect.
\end{abstract}

Key words: Early Sarmatian culture, Lower Don region, nomads, Hellenism, fortifications of Tanais, chronology.

Citation. Glebov V.P., Dedyulkin A.V., 2020. O vremeni poyavleniya rannih sarmatov na Nizhnem Donu [About the First Appearance of the Early Sarmatians in the Lower Don Region]. Nizhnevolzhskiy Arkheologicheskiy Vestnik [The Lower Volga Archaeological Bulletin], vol. 19, no. 2, pp. 92-119. DOI: https://doi.org/10.15688/ nav.jvolsu.2020.2.5

\section{О ВРЕМЕНИ ПОЯВЛЕНИЯ РАННИХ САРМАТОВ НА НИЖНЕМ ДОНУ}

\author{
Вячеслав Петрович Глебов \\ Археологическое научно-исследовательское бюро, г. Ростов-на-Дону, Российская Федерация
}

\section{Антон Владимирович Дедюлькин}

Южный федеральный университет, г. Ростов-на-Дону, Российская Федерация

Аннотация. В сарматологии существуют различные точки зрения относительно времени появления на Нижнем Дону носителей раннесарматской культуры II-I вв. до н.э. Большинство исследователей придержи- 
ваются мнения о довольно поздней дате освоения сарматами Нижнего Подонья и Северо-Восточного Причерноморья - не ранее второй половины II в. до н.э. Задачей исследования является определение даты прихода сарматов в Подонье на базе анализа данных сарматской и античной археологии, а также сведений нарративных и эпиграфических источников. В сарматских древностях по шкале относительной хронологии выделяется большой пласт ранних памятников в рамках II в. до н.э., однако количество хроноиндикаторов в сарматских погребениях этого горизонта сравнительно невелико. На основании родосской амфоры с клеймами, лаковых канфаров и «мегарских» чаш дата наиболее ранних комплексов может быть установлена в пределах второй или второй - третьей четвертей II в. до н.э. Приход сарматской миграционной волны вызвал общую дестабилизацию обстановки в Подонье и Северо-Восточном Причерноморье. На Боспоре фиксируются разрушение поселений и опустошение сельских территорий, на Нижнем Дону в Танаисе во второй четверти II в. до н.э. строится мощная система укреплений. Первые достоверные упоминания о сарматах в официальных документах относятся к концу первой - началу второй четверти столетия (договор 179 г. до н.э., дельфийские манумиссии). Появление сарматов в Нижнем Подонье и Северо-Восточном Причерноморье связывается нами с подвижкой кочевых племен в результате экспансии державы хунну, образовавшейся в конце III в. до н.э., докатившейся по принципу домино до южнорусских степей.

Ключевые слова: раннесарматская культура, Нижнее Подонье, кочевники, эллинизм, фортификация Танаиса, хронология.

Цитирование. Глебов В. П., Дедюлькин А. В., 2020. О времени появления ранних сарматов на Нижнем Дону // Нижневолжский археологический вестник. Т. 19, № 2. С. 92-119. DOI: https://doi.org/10.15688/ nav.jvolsu.2020.2.5

Целью данного исследования является уточнение времени появления на Нижнем Дону памятников раннесарматской культуры, традиционно датируемых в рамках II-I вв. до н.э. В Нижнем Подонье, в отличие от более восточных регионов, не прослеживается непрерывной линии развития раннесарматской культуры с IV по I в. до н.э. - сарматские памятники IV - начала III в. до н.э. и II-I вв. до н.э. разделены временным хиатусом. Кочевники II-I вв. до н.э. не являлись прямыми потомками нижнедонских номадов IV - начала III в. до н.э., а представляли собой новый миграционный импульс с востока, гораздо более мощный, чем в IV в. до н.э. На протяжении большей части III в. до н.э. в степной части Нижнего Подонья постоянное кочевое население, видимо, отсутствовало, можно предположить лишь эпизодическое проникновение отдельных групп номадов или военных отрядов [Глебов и др., 2005, с. 59-60; Глебов, 2007, с. 66]. Сходная ситуация - исчезновение погребальных памятников кочевников - наблюдается в это время и в соседних регионах - Поднепровье [Полин, 1992, с. 67-71], Предкавказье [Берлизов, 1996, с. 31; Шевченко, 2011, с. 50-51]. Плотное освоение нижнедонских степей носителями раннесарматской культуры произошло лишь во II в. до н.э., о чем свидетельствует появление здесь в большом количестве семейно-родовых сарматских могильников.
Относительно времени, причин и обстоятельств прихода этой миграционной волны существуют различные мнения.

М.П. Абрамова, рассмотрев известные к началу 60-х гг. прошлого столетия раннесарматские погребения Подонья и Северного Причерноморья, датировала их временем не ранее II в. до н.э. [Абрамова, 1961, с. 9599]. Однако Д.А. Мачинский, основываясь на сведениях письменных источников, высказал мнение, что Нижнее Подонье было сарматским уже в IV в. до н.э., а нашествие сарматов на Скифию, описанное Диодором (Diod., II, 43-46), имело место в конце IV - на рубеже IV-III вв. до н.э. [Мачинский, 1971, с. 4254]. Близкой точки зрения придерживался К.Ф. Смирнов, считавший, что хотя «основные массы ранних сарматов в IV-III вв. до н.э. жили еще за Танаисом-Доном, ...отдельные их отряды и даже племенные группы... прорывались уже далеко вглубь Скифии». По мере ослабления Скифии военное давление сарматов усиливалось и в III в. до н.э. это закончилось разорением и гибелью Великой Скифии [Смирнов, 1984, с. 66-72]. По мнению В.И. Костенко, этому длительному завоевательному периоду соответствуют немногочисленные разрозненные погребения, в основном воинские. Стабилизация обстановки в северопричерноморских степях и окончательное освоение их сарматами относят- 
ся ко времени не ранее II в. до н.э. [Костенко, 1983, с. 68-70].

Эти гипотезы легли в основу концепции сарматского разгрома Великой Скифии, в которой Подонью отводилась роль одной из тех территорий, откуда в конце первой трети III в. до н.э. совершались походы сарматов, ставшие причиной гибели Великой Скифии, а также разрушений и прекращения жизни на большинстве поселений греков и варваров в Северном Причерноморье [Виноградов и др., 1997, с. 101-103; Виноградов, 1997, с. 122-123].

Принципиально иная концепция была предложена С.В. Полиным. Проделав тщательный анализ скифских и сарматских комплексов Северного Причерноморья и прилегающих территорий, С.В. Полин пришел к выводу, что, во-первых, памятники номадов скифской эпохи в Северном Причерноморье исчезают в начале III в. до н.э. из-за резкого ухудшения природно-климатических условий, во-вторых, раннесарматские погребения якобы III в. до н.э. в большинстве своем неправильно датированы или неверно атрибутированы [Полин, 1992]. Согласно этой версии, никакого завоевания сарматами Великой Скифии не было, сарматы заняли пустующие причерноморские степи более чем через 100 лет после исчезновения скифов. Появление сарматов в Нижнем Подонье С.В. Полин относит ко II в. до н.э. [Полин, 2018, с. 280], первые сарматские комплексы на правобережье Дона датирует второй четвертью или серединой II в. до н.э., освоение сарматами донского правобережья и днепро-донского междуречья серединой - второй половиной II в. до н.э. [Полин, 1992, с. $68,81,117]$.

А.В. Симоненко в совместной с С.В. Полиным статье поддержал тезис о появлении сарматов в Северном Причерноморье не ранее середины II в. до н.э. [Полин, Симоненко, 1997, с. 96], однако в собственных работах А.В. Симоненко предпочитает более широкую хронологию памятников раннесарматского периода в Северном Причерноморье, не исключающую и первую половину II в. до н.э. [Симоненко, 1994, с. 45; 2004, с. 135-140; 2013, c. 205-206].

В.Е. Максименко на основании анализа нижнедонских древностей савроматского и раннесарматского времени сделал вывод о том, что сарматы-прохоровцы - это новая миграционная волна кочевников из Поволжья и Приуралья, вытеснивших носителей савроматской культуры предшествующего периода. По его мнению, сарматы-прохоровцы продвинулись с востока вдоль левого берега Дона в конце III в. до н.э. и переправились на правобережье в начале II в. до н.э. [Максименко, 1983, с. 128-129; 1997, с. 46-48; 2000, с. 161-162]. Вместе с тем В.Е. Максименко отмечал, что на донском левобережье ни одно прохоровское погребение не может быть с полной уверенностью продатировано концом III в. до н.э., а на правобережье сарматские погребальные комплексы появляются не ранее середины II в. до н.э. [Максименко, 1983, c. 48,65$]$.

В.П. Глебов, уточнив хронологию погребальных комплексов нижнедонских номадов, отнесенных В.Е. Максименко к IV-III вв. до н.э., пришел к заключению, что практически все они датируются не позже начала III в. до н.э., некоторые - II-I вв. до н.э., а на протяжении большей части III в. до н.э. в степном Нижнем Подонье, как и в Северном Причерноморье, отсутствуют кочевнические погребения, как сарматские, так и скифские [Глебов, 2002, с. 190-194; 2007, с. 64-66]. Выделив ранний горизонт раннесарматской культуры Нижнего Подонья и сопоставив датировки наиболее ранних комплексов со сведениями письменных источников, В.П. Глебов определил время освоения сарматами нижнедонского региона как конец III или рубеж IIIII вв. до н.э., а скорее всего, начало II в. до н.э. [Глебов, 2005 , с. $34-43 ; 2007$, с. 66-70; 2010, c. 22-23].

Н.Е. Берлизов на основании анализа сарматских погребений, поддающихся скольконибудь узкой датировке, отнес появление сарматских памятников в междуречье Волги и Дона к концу III в. до н.э., а на территориях к западу от Дона - к концу II в. до н.э. [Берлизов, 2011, с. 198-203].

В.Ю. Зуев разделяет памятники кочевников V-IV и II-I вв. до н.э. уральского региона на отдельные культуры (соответственно филипповскую и прохоровскую), друг с другом генетически не связанные и разделенные хиатусом III в. до н.э. Появление сарматовпрохоровцев в Поволжье и Подонье В.Е. Зуев 
относит ко времени не ранее второй половины или последней трети II в. до н.э. [Зуев, 1998, c. $18-19 ; 2000$, с. 94-97; 2013, с. 514-520], допуская сложение прохоровской культуры гдето «в землях, лежащих к востоку от Каспийского моря» в более раннее время - в конце III - первой четверти II в. до н.э. [Зуев, 2000, c. 96-99].

Развернутая гипотеза, увязывающая археологические данные и письменные источники о сарматах Северного Причерноморья с историческими событиями, происходившими далеко на востоке, принадлежит А.С. Скрипкину. Волгоградский исследователь выделяет сарматские памятники II-I вв. до н.э. в заключительный этап раннесарматской культуры, характеризующийся, среди прочего, большим количеством инноваций восточного облика, зачастую очень близких китайским, хуннским, южносибирским, среднеазиатским образцам: длинные мечи с небольшими ромбическими перекрестьями, миниатюрные бронзовые модельки котлов и горитов, ложковидные наконечники ремней, мечи с кольцевыми навершиями, бронзовые ажурные пряжки с изображением лежащих верблюдов или сцен терзания верблюда кошачьим хищником, гагатовые поясные пряжки, а также некоторые элементы погребального обряда: гробовища с двумя параллельными выступами в головной части, северная ориентировка погребенных [Скрипкин, 2000, с. 17-26; 2017, c. 151-158]. В появлении в волго-донских степях новой волны номадов восточного происхождения А.С. Скрипкин видит результат миграционных процессов, вызванных экспансией державы хунну, возникшей в конце III в. до н.э., вытеснением юэчжей из Ганьсуского коридора в Семиречье и последующим уходом их вместе с другими племенами в центральные и южные районы Средней Азии. Вторжение новых кочевников в Среднюю Азию привело к падению Греко-Бактрийского царства в 140 130 гг. до н.э., хотя давление номадов на Греко-Бактрию, вероятно, начало ощущаться раньше - предположительно, с середины II в. до н.э. ${ }^{1}$ [Скрипкин, 2017, с. 99]. С вторжением кочевников, сокрушившим Греко-Бактрийское царство, связывается возникновение огромных курганных могильников с подбойными и катакомбными погребениями в некоторых рай- онах Средней Азии [Вайнберг, 1992, с. 119121; Мандельштам, 1992, с. 107-115; Обельченко, 1992, с. 68-90, 219-228].

А.С. Скрипкин обратил внимание на сходство ситуации в столь отдаленных друг от друга областях, как Средняя Азия и восточноевропейские степи - в обоих этих регионах примерно в одно и то же время массово появляются новые памятники и фиксируются неизвестные ранее этнонимы: тохары, асии, пасианы, сакарауки в Бактрии, верхние аорсы, аорсы, сираки, роксоланы, сатархи в Сарматии (Strab., VII, 3; IX, 8, 2; XI, 5, 8), и предположил, что это звенья одной цепи. По его мнению, «все это свидетельствует об освоении степей юга Восточной Европы в рассматриваемый период племенами, принимавшими участие в среднеазиатских событиях» [Скрипкин, 2017, с. 161]. Основываясь на дате падения Греко-Бактрийского царства, А.С. Скрипкин определяет время прихода новой миграционной волны в волго-донской регион приблизительно серединой II в. до н.э. [Скрипкин, 2000, c. 27-29; 2017, с. 99].

Таким образом, расхождения во мнениях о времени и причинах появления ранних сарматов в волго-донских и причерноморских степях весьма значительны. Появление новых данных и новых гипотез дает нам повод вновь вернуться к этому вопросу.

Начнем с хронологии раннесарматских древностей. Анализ взаимовстречаемости различных типов вещей позволяет выделить в вещевом материале нижнедонской раннесарматской культуры две хронологические группы [Глебов, 2004, с. 127-128; 2010, с. 15-16].

На раннем этапе колчанные наборы состоят главным образом из железных черешковых наконечников стрел с трехгранными головками или трехлопастными головками с невыраженными лопастями, часто с длинными гранеными черешками. Наборы железных втульчатых наконечников стрел очень редки, наборы бронзовых наконечников стрел отсутствуют, зафиксированы лишь единичные находки. Среди клинкового оружия преобладают мечи с серповидными навершиями, хотя встречаются и экземпляры с кольцевидными навершиями. Зеркала представлены преимущественно образцами большого диаметра с клиновидной ручкой и валиком по 
краю. Основу керамического комплекса составляют лепные сосуды, среди которых довольно много округлодонных и выпуклодонных форм, импортная посуда встречается относительно редко. Из ранних вещей можно еще назвать восьмерковидные пряжки с неподвижным язычком, чашевидные курильницы и др.

Со временем в вещевом комплексе раннесарматской культуры Нижнего Подонья происходят изменения: господствующим типом клинкового оружия становятся мечи с кольцевидными навершиями, в колчанных наборах начинают преобладать трехлопастные наконечники с выраженными лопастями, с короткими или средними черешками, зеркала с валиком по краю постепенно сменяются зеркалами в виде плоского диска небольшого диаметра, округлодонные лепные сосуды почти исчезают, количество лепной посуды уменьшается, процент кружальной импортной посуды (боспорской, кубанской, предкавказской) растет.

Следует оговориться, что это деление материала на хронологические группы достаточно условно. Во-первых, вещи ранней хронологической группы часто запаздывают, иногда доживают до финала раннесарматской культуры, известны даже в среднесарматское время. Во-вторых, многие из вещей поздней хронологической группы (мечи с кольцевидными навершиями, зеркала в виде плоского диска небольшого диаметра) начинают встречаться уже на раннем этапе. Тем не менее исследователи обычно относят сарматские погребения и могильники с вещами раннего облика (особенно в сочетании друг с другом) к раннему этапу в рамках периода II-I вв. до н.э., что представляется нам вполне резонным, за исключением случаев, когда можно предположить запаздывание.

Наиболее ранние памятники тяготеют к восточным районам донского левобережья, среднему течению и низовьям рек Сал и Маныч. Здесь они исследованы в большом количестве: могильники Подгорненские, Ясырев, Попов, Холодный, Донской, Веселый, Отрадный, Усьман, Балабинский и др. Ранние комплексы выявлены также в низовьях Дона в могильниках Койсуг, Кулешовка, Красногоровка, Высочино и др.
На правом берегу Дона ранних комплексов значительно меньше. Вещи ранней хронологической группы присутствуют и здесь мечи с серповидными навершиями (Поляков, кург. 3, погр. 5; Северо-Западный I, кург. 1, погр. 8), зеркала большого диаметра с валиком по краю (Новочеркасская ГРЭС, кург. 2, погр. 12; Ливенцовский VII, кург. 19, погр. 1, кург. 22, погр. 7; Золотые горки IV, кург. 9, погр. 2; Кадамовский, разрушенный курган), округлодонная лепная посуда (Керчик, кург. 16, погр. 11; Ливенцовский VII, кург. 14A, погр. 2 , 3, 7, 9, кург. 20, погр. 3; Роща, кург. 1, погр. 8; Св. Колодезь III, кург. 1, погр. 1; Кастырский VIII, кург. 3, погр. 2) ${ }^{2}$. Однако в большинстве погребений ранние вещи единичны и могут запаздывать. Яркий пример кург. 1 мог. Северо-Западный I, где в семейно-родовом могильнике (пять сарматских захоронений, составляющих ряд) в одном из комплексов (погр. 8) был найден меч с серповидным навершием, а в соседнем (погр. 3) лучковая фибула [Власкин, 2000, с. 10-12, рис. $2,7,4,1]$.

Традиционно ситуацию с неравномерным распределением ранних памятников в Нижнем Подонье принято объяснять тем, что сарматами прежде было освоено донское левобережье, а на правый берег первоначально переправились лишь отдельные группы номадов, и только со временем, не ранее середины второй половины II в. до н.э., сарматы освоили донское правобережье и продвинулись далее на запад. Заметим, что такая картина, возможно, отражает не только очередность занятия сарматами территорий на левом и правом берегах Дона, но и особенности рельефа долины р. Дон. На правобережье памятников раннесарматской культуры вообще относительно немного - чуть более сотни. Скорее всего, малочисленность сарматских погребений на правом берегу объясняется отсутствием у него поймы. Памятники левобережья (их насчитывается около 400) тяготеют к обширной пойме, террасам и ближайшим водоразделам рек Дон, Сал, Маныч. Аналогичная ситуация - концентрация сарматских памятников в левобережной пойме и весьма скромное число их на правом берегу, отмечена и для волгоградского Подонья [Мамонтов, 2000 , c. 84]. 
Так или иначе, очевидно, что правобережные памятники в целом запаздывают по сравнению с левобережными, но вряд ли на полвека или даже больше, как считают некоторые исследователи. О том, что сарматы перебрались через Дон довольно рано, свидетельствует наличие сарматских комплексов раннего облика с мечами с серповидными навершиями, втульчатыми железными наконечниками стрел, зеркалами с валиком по краю и клиновидной ручкой, округлодонными лепными сосудами далее к западу, в доноднепровском междуречье и левобережном Поднепровье: Червонопартизанск, Виноградное, Преображенка, Жемчужное, Терны, Привольное, Большая Белозерка, Соколово, Днепрозаводстрой, Хорол, Сергеевка и др. [Симоненко, 1994; 2004, с. 135-140, рис. 1-4; 2007, c. 99-102; 2019]. А.В. Симоненко считает наиболее ранними в Северном Причерноморье (период I, фаза A1) комплексы с крупными фибулами среднелатенской схемы со скрепой (В-Костшевский), которые он датирует по аналогии с застежками оксывской и пшеворской культур первой половиной II в. до н.э. [Симоненко, 2001, с. 78-79; 2004, с. 157; 2013, с. 206]. Однако анализ взаимовстречаемости фибул с другими датирующими вещами в позднескифских и сарматских комплексах показывает, что появление застежек среднелатенской схемы в Северном Причерноморье произошло не ранее второй половины или последней четверти II в. до н.э. [Кропотов, 2010, с. 43-44].

Отдельного упоминания заслуживает ритуальный клад из кургана у пос. Острый в Донецкой области, содержащий в числе прочих вещей меч с серповидным навершием и «двутавровой» рукоятью, все аналогии которому происходят из сарматских комплексов III-II вв. до н.э. южно-уральского региона [Федоров, 2013, с. 43-45]. Найденные в этом кургане фрагменты амфор А.В. Симоненко датировал концом третьей - последней четвертью III в. до н.э., а сам комплекс - концом III - II в. до н.э. [Симоненко, 2007, с. 106-109]; правда, определения А.В. Симоненко амфорного материала из Острого вызывают вполне обоснованные, на наш взгляд, сомнения [Зайцев, 2012, с. 65].

Таким образом, с датировкой наиболее ранних сарматских комплексов в Северо-Во- сточном Причерноморье все достаточно неопределенно. В большинстве же сарматских погребений отсутствуют вещи, способные дать узкую дату.

Похожая картина наблюдается и на Нижнем Дону. Предметы импорта, встреченные в сарматских погребениях - лаковые канфары, «мегарские» чаши, унгвентарии, фибулы и пр., позволяют установить хронологию раннего этапа нижнедонской раннесарматской культуры приблизительно в пределах ІІ в. до н.э. Однако при попытках определить узкие даты наиболее ранних комплексов мы сталкиваемся с тем, что эти импорты в большинстве случаев бытуют в широком диапазоне.

Единственный узкодатируемый артефакт - родосская амфора с клеймами эпонима Аристона II и фабриканта Аминты (рис. 1,1), встречен не в погребении, а в насыпи кургана 4 1-й Веселовской группы в составе комплекса, обозначенного в публикации как «тризна I-II» [Мошкова, Максименко, 1974, с. 42, табл. XXII, 1-3, XXV,1-4]. Деятельность Аристона II относится к периоду IIIе (169/167-164/162 гг. до н.э.) хронологической схемы Дж. Финкельштейна [Finkielsztejn, 2001, p. 123, 124, 192, 193]. Вместе с амфорой были найдены три лепных сосуда, точильная плитка и кость КРС. Лепные сосуды по форме и орнаментации вполне вписываются в раннесарматскую керамическую традицию. Несколько необычен, пожалуй, лишь высокий узкодонный горшок с раздутым туловом и раструбным горлом [Мошкова, Максименко, 1974, табл. XXV,4], однако сосуды похожей формы иногда попадаются в сарматских погребениях: Подгорненский IV, кург. 5, погр. 5; Попов, кург. 50/18, погр. 10; Темерницкий I, кург. 6, погр. 7; Поляков, кург. 5, погр. 3 и др.

Канфары с орнаментом в стиле West Slope (рис. 1,4,5) встречены в двух комплекcax: Кулешовка I, кург. 1, погр. 29А [Глебов, 2017, рис. 6,1], Веселый, кург. 2, погр. 6 [Артамонов, 1949, рис. 19; Глебов, 2005, рис. 3,1]. Т.В. Егорова первоначально датировала канфары с S-видным профилем первой четвертью II в. до н.э. или несколько более поздним временем [Егорова, 2009, с. 50]. Однако позже она пересмотрела свою точку зрения и отнесла производство этих сосудов к периоду с конца III в. до н.э. до середины или третьей 
четверти II в. до н.э. [Егорова, 2018, с. 516; 2020 , с. 174, илл. 2]. Таким образом, находки эллинистических канфаров с S-видным профилем не позволяют как-то уточнить дату комплексов в пределах II в. до н.э., особенно если учесть возможность довольно долгого их бытования. Наглядным примером продолжительности использования чернолаковой керамики является канфар с росписью в стиле West Slope из погребения 1в могильника меотского Старокорсунского городища № 2. Сосуд с хорошей сохранностью лака и краски, датируемый 270-260 гг. до н.э., был найден вместе с родосской амфорой с клеймом эпонима Аристонида, 206 г. до н.э. [Лимберис, Марченко, 2017, c. 188].

«Мегарские» чаши из донских сарматских комплексов (рис. 1,2,3), вероятно, ионийского производства. Ввоз «мегарских» чаш из Ионийской Греции в Северное Причерноморье начался во второй четверти II в. до н.э., был наиболее интенсивным во второй половине столетия и резко снизился к концу II в. до н.э. [Коваленко, 2002, с. 82, 91-93]. Безусловным хроноиндикатором II в. до н.э. «мегарские» чаши считаться не могут, так как «инерционно» они продолжают бытовать и в І в. до н.э. [Кропотов, Лесков, 2006, с. 32-37; Шевченко, 2013, с. 20-21]. Чаша из погр. 17 кург. 1 мог. Кулешовка встречена в раннем контексте - с мечом с серповидным навершием и наконечниками стрел с длинными гранеными черешками [Глебов, 2017, с. 145-146, рис. 4]. Чаша из погр. 3 кург. 1 мог. СевероЗападный I явно запаздывает - она найдена вместе с лучковой фибулой 1-го варианта [Власкин, 2000, с. 10, рис. 1,4, 2,7].

Лаковая миска эллинистического типа из погр. 1 кург. 26 мог. Валовый I (рис. 1,6) [Беспалый и др., 2007, табл. 78,5], вероятно, изготовлена в каком-то из неаттических центров. По материалам афинской агоры миски подобных пропорций и профилировки датируются в диапазоне с последней четверти III в. до н.э. до конца II в. до н.э. [Rotroff, 1997, fig. 60].

Унгвентарии с вытянутым туловом, высокой ножкой и высоким горлом (Алитуб, кург. 20, погр. 3; разрушенное захоронение у пос. Кадамовский; Подгорненский I, кург. 6, погр. 8 и др.) (рис. $1,7,8$ ) относятся к поздним типам веретенообразных унгвентариев и бы- туют в рамках II - первой половины I в. до н.э. [Anderson-Stojanovic, 1987, p. 109-110; Марченко, 1996, с. 41-44, рис. 6; Зайцев, Мордвинцева, 2004, с. 177-178].

Фибулы из раннесарматских погребений принадлежат к различным типам: среднелатенской схемы, фибулы-броши, ближе к рубежу эр появляются «воинские» фибулы, ранние варианты лучковых фибул (рис. 1,9-13). Наиболее интересны в плане датировки раннего горизонта раннесарматской культуры застежки среднелатенской конструкции. А.К. Амброз датировал их I в. до н.э. [Амброз, 1966, c. 21-22], Б.Ю. Михлин - концом II - серединой или третьей четвертью I в. до н.э. [Михлин, 1980, с. 199-201]. Позднее, вслед за пересмотром хронологии собственно латенских древностей, проявилась тенденция к удревнению таких фибул - появление их в Северном Причерноморье начали относить к первой половине или середине II в. до н.э. [Марченко, 1996, с. 32; Берлизов, Еременко, 1998, с. 26; Симоненко, 2001, с. 78-79; Глебов, 2009, с. 72]. Однако, как показало исследование В.В. Кропотова, основанное на гораздо более полной источниковой базе, появление в Северном Причерноморье фибул среднелатенской схемы, как скрепленных, так и надвязных, датируется второй половиной или последней четвертью II в. до н.э. [Кропотов, 2010, с. 44, 50].

Прочие импорты из раннесарматских погребений Нижнего Подонья относятся к более позднему времени: синопская амфора (Ливенцовский VII, кург. 30, погр. 5) конец II - начало или первая половина I в. до н.э., сковорода Айлесфорд (Алитуб, кург. 3, погр. 20) - 90-50 или 90-10 гг. до н.э., буролаковая чаша с изогнутыми отставленными ручками (Пирожок, кург. 7, погр. 5) - I в. до н.э. начало I в. н.э. Бронзовые ситулы (Арбузовский, кург. 7, погр. 8, несколько находок из ритуальных кладов) и котелки с подвижными ручками (Алитуб, кург. 5, погр. 29; Сагванский I, кург. 12, погр. 2, кург. 14, погр. 3 и др.) датируются в широком диапазоне - II-I вв. до н.э., однако, судя по контексту находок, тяготеют к комплексам финала нижнедонской раннесарматской культуры. Массовой категорией находок в сарматских погребениях является боспорская столовая посуда - в комплексах нижнедонской раннесарматской культуры учтено 
более 70 находок различных боспорских сосудов, чаще всего кувшинов. Однако большинство типов красноглиняной боспорской посуды датируются широко, обычно в рамках II-I вв. до н.э. или даже шире, в силу этого они редко способны уточнить дату кочевнических комплексов, в которых найдены.

Подведем итог краткому анализу импортов, маркирующих комплексы раннего горизонта нижнедонской раннесарматской культуры. Родосская амфора с клеймами из 1-й Веселовской группы датируется 60-ми гг. II в. до н.э. Хронология лаковых мисок и канфаров с орнаментом в стиле West Slope не исключает и конца III - первой четверти II в. до н.э., но такая датировка комплексов, в которых они найдены, представляется нам маловероятной. Косвенно это подтверждает находка канфара в семейно-родовом могильнике в кургане 1 у с. Кулешовка (погр. 29А), хронология которого устанавливается в пределах второй - третьей четверти II в. до н.э. [Глебов, 2017, c. 146-151], датировать серию захоронений из кургана 1 более ранним временем не позволяет «мегарская» чаша из погр. 17. В Северном Причерноморье находки канфаров с S-видным профилем зафиксированы в самом разном контексте и в очень широком хронологическом диапазоне [Егорова, 2018, с. 516]. Из хорошо датированных комплексов следует упомянуть жертвенник в кургане у станицы Вышестеблиевской на Тамани с обломками подобных канфаров, «мегарской» чашей и родосской амфорой с клеймами фабриканта Марсия и эпонима Сосикла (158-154 гг. до н.э.) $\left[\right.$ Паль, 2018, с. 255 , рис. 6] ${ }^{3}$. Прочие импорты не могут маркировать погребения раннего горизонта, так как время их производства и бытования включает и I в. до н.э. На наш взгляд, наиболее вероятная дата для ранних комплексов нижнедонской раннесарматской культуры с импортами-хроноиндикаторами может быть устанавлена в пределах второй, или, возможно, второй - третьей четвертей II в. до н.э.

Не исключено, что некоторые могильники (Подгорненские I, IV-VI, Попов, Ясырев I и III, Холодный, Донской, Койсуг и др.), в которых преобладают вещи раннего облика, могут относиться к несколько более раннему времени. Однако при наличии в этих памят- никах вещей, характеризующих заключительный этап раннесарматской культуры (колчанные наборы из железных наконечников стрел, в подавляющем большинстве черешковых, мечи с кольцевидными навершиями, прямоугольные рамчатые пряжки с изображением лежащего верблюда, модельки котелков и горитов, каменные «молоточки» и др.), в них отсутствуют индикаторы III - ранней части II в. до н.э. - смешанные наборы бронзовых и железных наконечников стрел ${ }^{4}$, втоки копий, бронзовые ворворки, лепные сосуды с примесью талька в тесте [Клепиков, 2000, с. 117119; Клепиков, Скрипкин, 2002, с. 66-68; Скрипкин, 2017, с. 91]. Таким образом, даже самые ранние по шкале относительной хронологии сарматские памятники Нижнего Подонья вряд ли могут претендовать на датировку поздней частью III - началом II в. до н.э.

Итак, комплексы раннего горизонта нижнедонской раннесарматской культуры отчетливо выделяются по шкале относительной хронологии, но их абсолютное датирование строится на очень небольшой базе - фактически, на единичных находках. На весь пласт сарматских погребений раннего этапа (около 150 комплексов) приходится всего несколько артефактов, способных дать абсолютные даты. Количество импортных предметов в раннесарматских комплексах вообще невелико в сравнении со скифскими или меотскими памятниками, что затрудняет датирование сарматских комплексов и делает проблематичным построение дробной периодизации раннесарматской культуры на основе импортов-хроноиндикторов. Кроме того, даже когда вещи способны дать узкую дату (как в случае с амфорой из 1-й Веселовской группы), всегда существует вероятность их запаздывания.

Для проверки наших выводов сопоставим хронологию нижнедонской раннесарматской культуры с данными античной археологии и сведениями письменных источников.

Событие, вероятно, имеющее прямую связь с появлением сарматов в Нижнем Подонье - это строительство укреплений в Танаисе. Следы каких-либо оборонительных сооружений периода раннего Танаиса, несмотря на многолетние раскопки городища, не выявлены. На протяжении большей части III в. до н.э. 
Танаис обходится без серьезных укреплений, очевидно потому, что в этот период отсутствовала опасность нападений номадов - памятники кочевников на протяжении большей части III в. до н.э. в нижнедонской степи не известны. И лишь возникновение угрозы со стороны пришедших с востока носителей раннесарматской культуры подвигло жителей Танаиса на строительство полноценной системы обороны, включающей основной четырехугольник стен («цитадель»), стены западного городского района и западного пригорода. Итоги многолетних раскопок позволили исследователям реконструировать весь комплекс укреплений - стены с башнями и протейхизмой, ров, проходивший вдоль восточного и северного края цитадели и опоясывавший пригород и западный район, а также, помимо собственно городских укреплений, внешняя линия обороны - один или два вала со рвами на расстоянии от 50 до 200 м к С, В и 3 от городских стен, с напольной стороны [Ильяшенко и др., 2015, с. 179-187]. Таким образом, в Танаисе в первой половине II в. до н.э. была создана мощная эшелонированная система укреплений, обращенная в сторону степи. Это трудоемкое и дорогостоящее мероприятие, очевидно, было мотивировано угрозой самому существованию города, созданной сарматами, занявшими в это время нижнедонские степи [Глебов, 2007, с. 68-69; 2010, с. 22; Глебов, Ильяшенко, 2019, с. 81-82]. Со временем отношения кочевников и жителей Танаиса, видимо, стабилизировались, письменные источники говорят об активной торговле с сарматами (Strab., XI, II, 3), следы каких-либо боевых действий не зафиксированы, рвы со временем затекают землей и мусором и подновляются только перед нападением Полемона.

На взаимосвязь создания системы обороны Танаиса с возникновением сарматской угрозы первым обратил внимание С.В. Полин, определивший дату возведения укреплений в Танаисе со ссылкой на мнение Д.Б. Шелова как вторую четверть или середину II в. до н.э. [Полин, 1992, с. 68, 117]. Это не совсем таквремя возведения крепостных стен Танаиса было определено Д.Б. Шеловым в пределах конца III - начала II в. до н.э. на основании находок синопского и родосского клейм в слое на уровне основания стены 5 [Шелов, 1970, c. $114-115$; 1975 , с. 113 , кат. 428 , с. 140 , кат. 557]. По современным представлениям датировка клейма синопского астинома Дионисия, сына Дионисия, внука Клейтагора, должна быть удревнена - примерно до 205-195 гг. до н.э. [Кац, 2007 , с. 441, № 158], или до 220 г. до н.э. [Федосеев, 2017, с. 184, № 42-45], а деятельность родосской женщины-фабриканта Никагиды относится к более позднему времени - периоду III схемы Дж. Финкельштейна, 198161 гг. до н.э. [Кац, 2007, с. 423]. Несмотря на эту корректировку, общая дата обоих клейм осталась прежней. В публикациях результатов исследований участка, где смыкаются куртины 5 и 5А, участка с башнями 3 и 4, а также прилегающей части стены западного городского района, для наиболее ранних укреплений была принята дата, предложенная Д.Б. Шеловым [Арсеньева, Науменко, 2004, с. 29; 2006, c. 21; Арсеньева и др., 2010, с. 316]. Рубеж III-II вв. до н.э. был принят и в качестве времени строительства северной стены 37 западного пригорода [Циркунова 2008, с. 384], эта датировка некоторыми исследователями используется вплоть до настоящего времени [Егорова, 2020, с. 174]. В публикации, посвященной оборонительным рвам Танаиса II-I вв. до н.э., возведение стены 37 западного пригорода было отнесено к первой четверти II в. до н.э. [Ильяшенко и др., 2015, с. 183], а время формирования всего комплекса фортификационных сооружений города определено в рамках первой половины II в. до н.э. [Ильяшенко и др., 2015, с. 187].

В распоряжении Д.Б. Шелова был достаточно ограниченный материал, на основании которого исследователь дал максимально объективную на тот момент датировку. Подробные публикации результатов исследований куртин 5 и $5 \mathrm{~A}$, а также башни 3 [Арсеньева, Науменко, 2004; 2006] ввели в научный оборот представительную серию родосских и несколько синопских клейм, что позволяет уточнить время и последовательность строительства укреплений Танаиса. Хронология синопских клейм представлена в настоящее время в четырех вариантах - Н. Коновичи, достаточно близких между собой схем И. Гарлана и В.И. Каца, а также системой Н.Ф. Федосеева, в которой нет групп и для каждого астинома предложена датировка. Во 
всех этих схемах расхождения в количестве магистратов минимальны, соответственно примерно одинаково определяется продолжительность синопского клеймения. Однако на данном этапе датировки многих синопских клейм менее надежны, чем родосских, поскольку нет единства мнений относительно даты начала и прекращения астиномного клеймения в Синопе. Для большинства родосских эпонимов, датировка которых указана по схеме Дж. Финкельштейна, разброс возможных вариантов не превышает 10 лет.

Материалы, предшествующие строительству укреплений. Из ям, перекрытых материковым грунтом, снятым при возведении стен 5 и 5А, происходят два синопских клейма. Эмблема Ника на колеснице-биге принадлежит астиному Каллисфену, сыну Гестиея [Garlan, 2004, p. 87-88], время деятельности которого определялось В.И. Кацем около 259 г. до н.э. [Кац, 2007, с. 439, № 102], а Н.Ф. Федосеевым - 231 г. до н.э. [Федосеев, 2017, с. 195, № 99, 101, 102]. Второе клеймо принадлежит астиному Анфестерию сыну Невмения, деятельность которого по В.И. Кацу относится к 250-м гг. до н.э. [Кац, 2007, с. 440, № 110], по Н.Ф. Федосееву - к 238 г. до н.э. [Федосеев, 2017, с. 195, № 99, 101, 102].

Время строительства укреплений ${ }^{5}$. Принципиальное значение имеют находки родосских клейм из башни 3 , поскольку она возведена на едином фундаменте с куртиной 5А основного четырехугольника городища, а их стены построены в переплет - то есть башня и куртина строились одновременно [Арсеньева, Науменко, 2004, с. 30-31; Арсеньева и др., 2010 , с. 318 ]. Наиболее раннее клеймо - эпонима Симилина (период IIb, 219-211 гг. до н.э., возможно чуть позже) - найдено в канавке под слоем самого нижнего пола; к самой башне это клеймо не имеет отношения. В яме 1 в юго-западной части башни найдено клеймо фабриканта Диодота (период III, 198-161 гг. до н.э.). В слое на новых каменных ступенях внутри башни найдено клеймо фабриканта Аристокла II (его клейма сочетаются с эпонимами периодов IIId-Vc, 170-117-е гг. до н.э.). Под вымосткой из крупных плит (фаза 2), выше глинистых полов 1 и 2, примазанных к стенам башни, было клеймо эпонима Архилаида (169/ 167-164/162 гг. до н.э.). В слое поверх вымос- тки из крупных плит (фаза 2) было клеймо фабриканта Фесмокрита (период V, 145108 гг. до н.э.). Около входа, в слое поверх вымостки из крупных плит найдено клеймо эпонима Астимеда II (144 г. до н.э.). За внешними стенами башни, в яме 2, было найдено клеймо эпонима Симмаха (175/173-173/171 гг. до н.э.). В мусорном слое над ямами 1 и 2 за внешними стенами башни обнаружено клеймо фабриканта Агоранакта (период III, 198161 гг. до н.э.). Судя по клеймам Фесмокрита и Астимеда II, вымостка перед входом и внутри башни была сделана после строительства башни, в 150-140-е гг. до н.э.

Учитывая, что стены 5, 5А и башня 3 являются самыми ранними из исследованных укреплений, важнейшим хронологическим репером является найденное на самых ранних глиняных полах башни 3 под плитами вымостки клеймо эпонима Архилаида (169/167-164/ 162 гг. до н.э.) - terminus ante quem для башни и стен Танаиса. Обустройство полов производилось на завершающем этапе строительства, после выведения стен и перекрытий башни. Следовательно, время строительства башни надо датировать в рамках 70-х - первой половины 60-х гг. II в. до н.э.

Период после строительства укреплений. Из слоя мостовой, расположенной с внешней стороны стен 5 и $5 \mathrm{~A}$, происходит представительная серия родосских клейм: эпонима Пифодора (150-147 гг. до н.э.), фабриканта Нания (период IV, 160-146 гг. до н.э.), эпонима Аристомаха I (157-155 гг. до н.э.), фабриканта Агоранакта (период III, 198161 гг. до н.э.), эпонима Тимуррода (159/158 гг. до н.э.), фабриканта Каллона (145-108 гг. до н.э.), эпонима Аристогейта (140-138 гг. до н.э.). В слое над мостовой представлены следующие родосские клейма: фабриканта Драконтида (периоды IV-V, 160-108 гг. до н.э.), эпонима Павсания III (152 г. до н.э.), фабриканта Зенона II (период III, 198-161 гг. до н.э.). В шурфе 1, примыкавшем к куртине 5, обнаружена мостовая, при зачистке которой выявлены родосские клейма: эпонима Архилаида (169/167-164/162 гг. до н.э.), фабриканта Агесила (его клейма сочетаются с эпонимами периода IIIa, 198-190 гг. до н.э.), эпонима Алексимаха (150-147 гг. до н.э.). Кроме того, здесь же найдено одно книдское клеймо эпо- 
нима Полита и фабриканта Никасибула (период III, 220-188 гг. до н.э. по В. Грэйс, 255215 гг. до н.э. по Н.В. Ефремову) [Внуков, Ефремов, 2017, с. 78] - возможно, попало сюда случайно, но скорее всего, столь ранняя дата объясняется недостаточной разработанностью хронологии книдских клейм [Внуков, Ефремов, 2017, с. 78-79]. В шурфе 2, примыкавшем к куртине 5 А, в слое мостовой обнаружено несколько родосских клейм: фабриканта Полемона (период V, 145-108 гг. до н.э.), эпонима Дамайнета (159/158 гг. до н.э.). Хронология родосских клейм позволяет предположить, что мостовые вдоль стен строились позже башен и куртин - в 150-140 гг. до н.э., что отмечали и исследователи Танаиса [Aрсеньева, Науменко, 2006, с. 21].

Вывод. Клейма III в. до н.э. никак не связаны со строительством укреплений Танаиса - они найдены либо около стен, либо в ямах и неровностях более раннего времени ${ }^{6}$. Период основных фортификационных работ строительство стен и башен выпадает на начало и середину второй четверти II в. до н.э. Некоторые работы (достройка башен, мощеная дорога вдоль стен и пр.) продолжались и после возведения основных укреплений, в конце второй - начале третьей четверти столетия и, вероятно, позже.

Строительство укреплений в Танаисе не единственный факт, указывающий на некую внешнюю угрозу, возникшую в начале II в. до н.э. Различные свидетельства дестабилизации обстановки - возведение или обновление укреплений, сокрытие кладов, следы разрушений и запустение хор городов - фиксируются в это время в различных областях $\mathrm{Ce}$ верного Причерноморья: на Боспоре [Macленников, 1995 , с. $93 ; 1999$, с. 186], в Крымской Скифии [Колтухов, 1999, с. 32 и сл.; Зайцев, 2017, с. 127], в Херсонесе [Щеглов, 1978, c. 130-131; Кац, 1994, с. 71-77; Гилевич, 1973, c. 11], в Ольвии [Буйских, 1986, с. 24; Крыжицкий, Лейпунская, 1988, с. 28-30], в Тире [Самойлова, 1988, с. 100; Булатович, 1997, c. 226]. Возможно, дестабилизирующим фактором для Северного Причерноморья в начале II в. до н.э. являлись не одни сарматы. Приблизительно в это же время существовала и достаточно реальная угроза с запада - галаты и скиры, а также, возможно, бастарны [Ca- мойлова, 1988, с. 100; Щукин, 1994, с. 116-119]; разрушения на хоре Херсонеса традиционно принято связывать с действиями скифов [Щеглов, 1978, с. 131]. Однако события в Нижнем Подонье (строительство укреплений в Танаисе) и в Крыму (разрушения поселений и опустошение сельской территории европейского Боспора) с наибольшей вероятностью могут быть связаны с продвижением на Нижний Дон и в Северо-Восточное Причерноморье носителей раннесарматской культуры.

Дату этих событий позволяют уточнить данные нарративных и эпиграфических источников. Как известно, сведения о сарматах появляются у античных авторов IV-III вв. до н.э., однако С.В. Полиным и А.В. Симоненко убедительно доказано, что все упоминания сарматов в этих источниках неопределенны, спорны, часто носят легендарный характер и не дают никаких оснований для предположения о массовом проникновении сарматов в Северное Причерноморье ранее II в. до н.э. [Полин, Симоненко, 1997, с. 87-96]. Сведения о сирматах на р. Танаис, приводимые авторами IV в. до н.э. Эвдоксом Книдским (Eud., I, 1) и Псевдо-Скилаком (Ps.-Skil., 68), видимо, относятся к памятникам номадов восточного происхождения, локализованных на правом и левом берегах р. Дон [Глебов, 2007, с. 61-62; 2010, с. 19]. Упоминание о сарматах в Крыму в декрете «О несении Диониса», датирующемся по данным палеографии не позднее первой четверти III в. до н.э. [Виноградов, 1997, с. 104-124], достаточно неопределенно из-за фрагментированности текста. Прочтение Ю.Г. Виноградова - «[готовилось вторжение] полчищ сарматов» и предположение о вывозе захваченных в плен херсонеситов в Сарматию - не более чем гипотеза. Локализация сарматов декрета «О несении Диониса» и характер их участия в описываемых событиях не могут быть определены однозначно.

Вероятно, первым надежно датированным источником, фиксирующим сарматов в Северо-Восточном Причерноморье, является договор 179 г. до н.э. между Фарнаком Понтийским и рядом малоазийских государств, в тексте которого среди европейских властителей упоминается сарматский царь Гатал

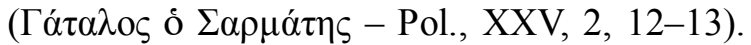
Свидетельство Полибия о сарматском царе 
Гатале имеет принципиальное значение, поскольку хорошо согласуется со временем дестабилизации в Северном Причерноморье. Мирный договор между Понтом, Малой Арменией и Пергамом, Вифинией, Каппадокией, в котором упоминается Гатал, относится к первому году 150-й олимпиады [Walbank, 1979, p. 20, 57, 271], то есть к 180-179 гг. до н.э. При этом совершенно не обязательно, что упоминаемый Полибием мирный договор, в котором царь Гатал и Херсонес указаны в числе гарантов, и известный эпиграфический памятник IOSPE I2, 402 - договор о союзе между Херсонесом Таврическим и Фарнаком I, близки по времени или синхронны. Поэтому возможные изменения датировки херсонесской надписи IOSPE I2, 402 [Габелко, 2012] никак не повлияют на датировку мирного договора, завершившего Понтийскую войну 183-179 гг. до н.э., в котором упоминается сарматский царь Гатал.

Вопрос о местонахождении царства Гатала не прояснен до конца. Мнение об отсутствии сарматских памятников II-I вв. до н.э. в Крыму и малочисленности их в Северном Причерноморье (по А.В. Симоненко - немногим более 50 погребений, несколько ритуальных кладов и отдельные находки - всего 74 комплекса [Симоненко, 2004, с. 134-136]) породило гипотезы о локализации владений Гатала в Прикубанье [Полин, 1992, с. 91-94, 121; Марченко, 1996, с. 124-126; Полин, Симоненко, 1997, с. 91-92], на Дону или даже в Поволжье [Скрипкин, 2017, с. 163]. Однако, судя по исследованиям В.В. Кропотова, сарматские захоронения в Крыму все же есть, а количество памятников раннесарматского периода Северного Причерноморья у А.В. Симоненко, видимо, занижено [Кропотов, 2016, c. $22-30 ; 2019$, с. $155-156]$. В случае корректировки численности раннесарматских памятников в этом регионе исчезает необходимость переносить куда-то царство Гатала, как и границу Европы и Азии, что само по себе спорно [Виноградов, 1997, с. 104-105, примеч. 3; Скрипкин, 2017, с. 163].

Расселение сарматов в нижнедонских и северопричерноморских степях и вступление их в контакты с местными греками, очевидно, маркируется появлением имен рабов-сарматов во II в. до н.э. в текстах дельфийских манумиссий (актов об отпуске рабов на волю под видом их продажи божеству). На этот важный источник первым обратил внимание Б.Н. Граков, включив в свою сводку и наиболее раннюю надпись с упоминанием сарматки Филы [Граков, 1939, с. 304-305]. С.В. Полин отметил, что этот факт косвенно фиксирует время появления сарматов в северопричерноморском регионе [Полин, 1992, с. 94]. А.В. Симоненко отметил, что из текстов манумиссий не следует именно северопричерноморское происхождение этих рабов [Симоненко, 1994, с. 33]. Нам ближе точка зрения С.В. Полина - очевидно, что речь идет о сарматах из Северного Причерноморья или из какого-то близкого региона - Подонья, Прикубанья, междуречья Дона и Волги. Безусловно, ближайшим пунктом для приобретения таких рабов был Танаис или какой-то из боспорских городов. Для восточных сарматов (прикаспийских, южноуральских), вероятно, были ближе рынки Хорезма и Парфии. В таком случае для того, чтобы рабы из восточных сарматов попали в Дельфы, придется представить какой-то сложный путь перепродаж их через Хорезм, Парфию, царство Селевкидов и т. д.

Следует подчеркнуть, что речь идет не о единичном случае, а целой серии манумиссий (10 рабов и рабынь в надписях из Дельф, 1 из Навпакта, 1 из Фискей в Локриде), а также надгробиях (3 из Аттики, 3 с Родоса), преимущественно относящихся к II в. до н.э. ${ }^{7}$ [Avram, 2007, p. 242-243]. Очевидно, что это следствие установления постоянных торговых связей северопонтийских греков с новыми соседями - сарматами, освоившими донские и причерноморские степи, а не случайное попадание на греческие рынки рабов из какихто дальних степных регионов. Б.Н. Граков отмечает, что рабы-скифы исчезают на греческих рынках со II в. до н.э., их заменяют сарматы [Граков, 1939, с. 291]. О продаже сарматами рабов боспорянам пишет Страбон (Strab. XI, II, 3), о перепродаже этих рабов далее на рынки Средиземноморья упоминает Полибий (Polib. IV, 38).

Манумиссии представляют значительный интерес для уточнения хронологии появления сарматов. Благодаря упоминаниям должностных лиц, они могут быть датированы с 
точностью до десятилетия, а иногда и до года. Примечательно, что С.В. Полин указал, что надписи с упоминанием сарматов появляются около середины II в. до н.э., эту же дату принимает А.В. Симоненко. Эта ситуация была обусловлена тем, что в сводке Б.Н. Гракова была приведена широкая датировка манумиссии Филы в рамках IV жречества, 170157/156 гг. до н.э. [Граков, 1939, с. 305]. А. Моммзен установил, что жрецы Аполлона, упоминаемые в дельфийских манумиссиях, исполняли свои обязанности пожизненно, по двое. Уже в XIX в. для жречеств были предложены хронологические группы [Никитский, 1894/95, с. 127-128], датировки которых в основном сохранили актуальность вплоть до настоящего времени, с некоторыми уточнениями. Сложнее обстояло дело с датировками архонтов из этих же надписей. В монографии Ж. До [Daux, 1943], опубликованной спустя четыре года после выхода статьи Б.Н. Гракова, была представлена хронологическая последовательность многих архонтов. Срок исполнения обязанностей Клеона, сына Диона, при котором была освобождена Фила, выпадает на 168/167 гг. до н.э. [Daux, 1943, p. 52]. Д. Мюлье предложил ряд уточнений относительно хронологии IV жречества, но датировка архонтства Клеона, сына Диона, осталась без изменений [Mulliez, 1998, p. 232]. Соответственно, речь идет не о середине II в. до н.э., а о начале второй четверти этого столетия. Помимо самой ранней надписи об освобождении Филы, шесть сарматов упоминаются в надписях [Avram, 2007, p. 242-243], относящихся к VI жречеству, датируемому Ж. До 153/2-144/3 гг. до н.э. [Daux, 1943, p. 55]. Эту датировку VI жречества разделяет и Д. Мюлье [Mulliez, 2006, p. 2237, 2244, 2254]. Две сарматки упоминаются в надписи, относящейся к VIII жречеству, датируемому Ж. До 142/141-140/139 гг. до н.э. Деятельность упоминаемого в надписи архонта Клевдама относится к 142/141 гг. до н.э. Самой поздней из дельфийских манумиссий является надпись с упоминанием сармата Сополия, которая относится к XII жречеству, датируемому Ж. До 113-100 гг. до н.э. [Daux, 1943, p. 62], Р. Бушон и Н. Кириакидис отодвигают верхнюю границу до 94/93 гг. до н.э. [Bouchon, Kyriakidis, 2017 , p. 218, renvoi 23]. Манумиссия из На- впакта датируется временем вскоре после 137/136 гг. до н.э., из Фискей в Локриде около середины II в. до н.э. [Avram, 2007, p. 243]. Таким образом, манумиссия Филы не является какой-то обособленной и уникальной.

Что касается времени появления сарматов в Северном Причерноморье, отметим еще одно интересное обстоятельство - рабынясарматка названа греческим именем Фила. Рабы из варварских земель, впервые попадавшие на греческие рынки, назывались не именами, а этниконами: сириец, иллириец, фракиянка, кариец и т. д. [Граков, 1939, с. 290], и только потом новые владельцы давали им греческие имена. Из этого следует, что женщина-сарматка была продана в рабство, прожила рабыней какое-то время в Греции, получив имя Фила, и только потом была освобождена в Дельфах. То есть с момента продажи ее до освобождения в 168/167 гг. до н.э. прошло, повидимому, несколько лет.

Итак, сведения нарративных и эпиграфических источников - упоминание царя Гатала и манумиссия Филы - являются terminus ante quem для появления ранних сарматов в Нижнем Подонье и Северо-Восточном Причерноморье.

Сопоставим даты рассмотренных нами различных групп источников. Данные сарматской и античной археологии очень близки: появление наиболее ранних сарматских комплексов практически совпадает со строительством укреплений в Танаисе во второй четверти II в. до н.э. Похожую дату дает и манумиссия Филы. Однако договор 179 г. до н.э., в котором фигурирует царь Гатал, фиксирует сарматов в Северном Причерноморье уже в конце первой четверти столетия, причем этот документ отражает реалии, сложившиеся несколько ранее - царство Гатала к моменту подписания договора уже существовало в течение какого-то времени.

Датирующие возможности рассмотренных источников неравноценны. Хронология сарматских памятников весьма приблизительна в силу очень небольшого количества узкодатирующих артефактов, содержащихся в кочевнических погребениях. Как уже отмечалось, мы не исключаем, что некоторые нижнедонские сарматские памятники могут датироваться несколько более ранним временем. 
Однако, что касается времени строительства укреплений в Танаисе, то оно определяется достаточно точно, благодаря хорошо разработанной хронологии амфорных клейм (в первую очередь родосских). Но наиболее достоверные и узкие даты - с точностью до года в нашем случае дают эпиграфические и нарративные источники. Датировка манумиссии Филы опирается на хорошо разработанную хронологию дельфийских жречеств и архонств, упоминание Полибием царя Гатала в связи с договором 179 г. до н.э. надежно привязано к дате окончания Понтийской войны. Никаких оснований не доверять этим источникам мы не видим. Небольшое запаздывание фортификации Танаиса по сравнению с появлением сарматов в Нижнем Подонье и Северном Причерноморье в общем-то неудивительно. Выполнение большого объема строительных работ при сравнительно скромных финансовых возможностях и ограниченных людских ресурсах затянулось на достаточно долгий срок, о чем свидетельствует хронология амфорных клейм.

Полученная нами дата появления сарматов в Подонье и Северном Причерноморье конец первой четверти II в. до н.э. - несколько более ранняя, чем у большинства исследователей, и не стыкуется с общепринятым мнением о завоевании Греко-Бактрии восточными номадами в $140-130$ гг. до н.э. ${ }^{8}$, что ставит под вопрос правомерность гипотезы о взаимосвязи этих событий.

Впрочем, А.С. Скрипкин допускает, что ряд миграций кочевников с востока, достигших Сарматии, могли произойти в период с начала образования хуннского объединения (самый конец III в. до н.э.) ${ }^{9}$ до падения Греко-Бактрии, и что какая-то часть кочевых племен, теснимых хунну, могла продвинуться на запад по степному коридору, минуя Среднюю Азию [Скрипкин, 2017, с. 99]. В таком случае эти миграционные группы восточных номадов могли попасть в волго-донские и причерноморские степи уже в первой четверти II в. до н.э. [Глебов, 2010, с. 25].

Очевидная преемственность погребальных традиций и вещевого материала не оставляет сомнений в том, что раннесарматская культура II-I вв. до н.э. развивалась главным образом на основе сарматских памятни- ков предшествующего периода. Однако исследователи отмечают при этом сильное восточное влияние, объясняя это включением в состав раннесарматской культуры миграционных групп среднеазиатского и южно-сибирского происхождения [Скрипкин, Клепиков, 2004, с. 99-100; Гуцалов, 2004, с. 122-124; Скрипкин, 2017, с. 161; Федоров, 2018, с. 189-190].

Основу мигрантов, вероятно, составляли сарматы из восточных и юго-восточных регионов Сарматии, где не были редкостью различные вещи восточного происхождения и ощущалось сильное влияние восточного хуннского и юэчжийско-усуньского мира. Эти группы пришельцев были близкородственны, если не идентичны, поволжским сарматам, но вместе с тем несли некоторые погребальные традиции и элементы материальной культуры, заимствованные у восточных соседей - своеобразную восточную «вуаль». Разумеется, это не исключает продвижения на территорию Сарматии отдельных групп собственно юэчжей-тохаров. Если принять версию об идентичности тохаров с тагорами, сатархами, тафриями эпиграфических и письменных источников, то надо признать, что какие-то восточные номады добрались до Нижнего Подонья и Северного Причерноморья [Десятчиков, 1973; Скрипкин, 2017, с. 161].

Очевидно, эти группы были малочисленными и быстро смешались с сарматами, так как археологически они не выделяются. Восточные элементы погребального обряда (северная ориентировка, гробы-колоды с выступами) редки, в ряде случаев зафиксированы в сарматских семейно-родовых могильниках, вещи восточного происхождения также чаще всего происходят из обычных сарматских погребений.

Таким образом, раннесарматская миграционная волна II в. до н.э. - это переселение части номадов из восточных регионов Сарматии (вероятно, с включением инородных групп), сдвинутых по принципу домино из мест обитания в результате подвижки кочевых племен евразийского степного коридора в начале II в. до н.э. Причиной этих миграционных процессов, видимо, послужила экспансия хуннской державы Модэ-шаньюя, еще до изгнания юэчжей при Лаошаншаньюе и завоевания ими Бактрии. Этот 
миграционный толчок привел к продвижению сарматов в первой четверти II в. до н.э. на территории к западу и юго-западу от Волги - в Нижнее Подонье, Северо-Восточное Причерноморье, Предкавказье.

\section{ПРИМЕЧАНИЯ}

1 Здесь уместно вспомнить знаменитую «угрозу Евтидема» о постоянной опасности для Бактрии и других государств региона со стороны кочевников, существовавшей уже в конце III в. до н.э. (Pol., XI, 34, 2-5). Евтидем не называет кочевников, угрожающих границам Бактрии, но, скорее всего, он имел в виду даев, об активности которых (в частности, о захвате даями-апарнами Парфии) во второй половине III в. до н.э. нам известно из других источников (Strab., IX, 9, 2; Just., XLI, 4, 6-9). Эта угроза была реализована несколько позже, во II в. до н.э., но уже другими номадами, пришедшими с северо-востока: «кочевники..., которые отняли у греков Бактриану - тохары, асии, пасианы и сакарауки, переселившиеся из области на другом берегу Яксарта» (Strab., XI, 8, 2) - они же большие юэчжи, усуни и сэ китайских хроник.

${ }^{2}$ Вероятно, к этому списку следует добавить погр. 1 кург. 26 мог. Валовый I - кенотаф, содержавший только лаковую миску II в. до н.э. [Беспалый и др., 2007, с. 66, табл. 78,1,5].

${ }^{3}$ В кратком сообщении Е.П. Паля не указываются типы канфаров. А.В. Дедюлькин, определявший по просьбе А.В. Кияшко амфорные клейма из этого комплекса, осматривал и остальную керамику. Вместе с амфорой и «мегарской» чашей было найдено два чернолаковых канфара с S-видным профилем.

${ }^{4}$ Известны единичные бронзовые наконечники стрел в колчанных наборах с железными наконечниками (Подгорненский I, кург. 1, погр. 9; Ясырев III, кург. 1, погр. 7) или отдельные находки (Под- горненский IV, кург. 30, погр. 7; Донской (Новочеркасская ГРЭС), кург. 5, погр. 23 и др.).

${ }^{5}$ Описание стратиграфии и контекста находок амфорных клейм дается по: [Арсеньева, Науменко, 2004; 2006].

${ }^{6}$ Ранний материал III в. до н.э. (херсонесское клеймо конца IV - начала III в. до н.э., родосское клеймо конца III - начала II в. до н.э., фрагмент терракоты) зафиксирован в нижней части более поздней башни 4-«северной», пристроенной к стене с внешней стороны [Арсеньева и др., 2010, с. 321, 318-319]. Полы, очаги, ямы в башне отсутствуют, нижняя часть башни, видимо, была забутована мусорным грунтом более раннего времени.

${ }^{7}$ Единственное упоминание рабыни-сарматки (?) Мелиссы в эпитафии из Рамнунта (Аттика) предположительно III в. до н.э. [Avram, 2007, p. 243] - случай не вполне очевидный. Отнесение этой эпитафии к III в. до н.э. основано лишь на данных палеографии. Этноним в надписи сохранился не полностью, хотя такое восстановление его выглядит достаточно вероятным.

${ }^{8}$ Существуют мнения о более ранней дате выхода юэчжей к границам Греко-Бактрийского царства - 145 г. до н.э. [Бернар, Абдуллаев, 1997, с. 68], конец 60-х гг. ІІ в. до н.э. [Боровкова, 2001, с. 111-114].

${ }^{9}$ Сведения об этих событиях мы можем почерпнуть из китайских летописей: «В прошлые времена процветания [царство] Юэчжи пренебрежительно относилось к хуннам. Когда же Маодунь вступил на трон, то напал и нанес поражение Юэчжи. А хуннский Лаошан-шаньюй убил правителя Юэчжи и сделал из его головы чашу для питья. Первоначально юэчжи жили между Дуньхуаном и Цилянь, а когда были разгромлены хуннами, ушли далеко, прошли к западу от Давань и нанесли удар по Дася (Бактрии)» («Ши цзи», гл. 123, с. 3161-3162). Правление шаньюя Маодуня (Модэ) современными исследователями относится к 205-174 гг. до н.э., правление его сына Лаошан-шаньюя - к 174-162 гг. до н.э. [Боровкова, 2001, с. 45-66]. 


\section{ИЛЛЮСТРАЦИИ}
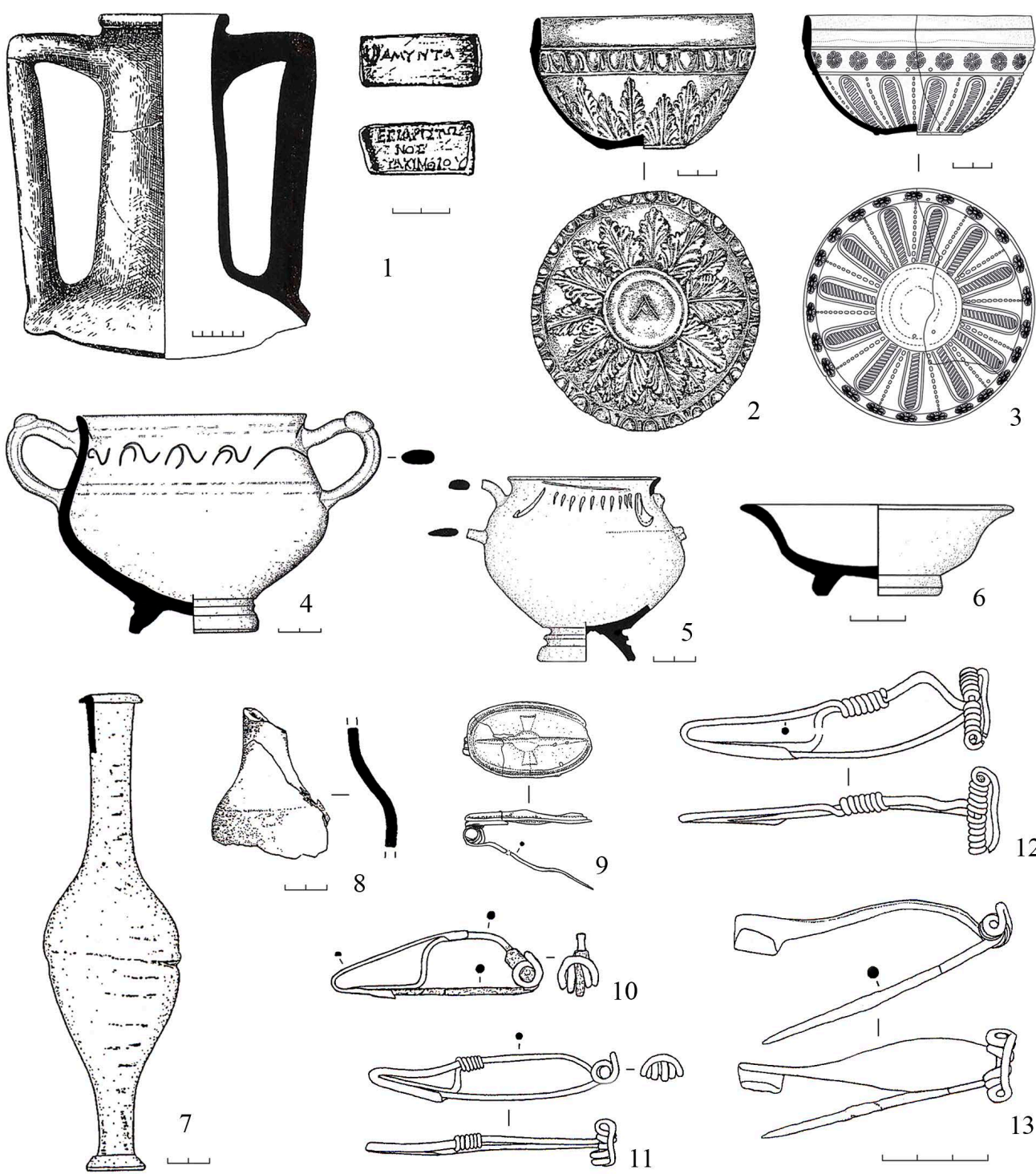

Рис. 1. Хронологические индикаторы из комплексов раннесарматской культуры Нижнего Подонья II-І вв. до н.э.:

1 - 1-я Веселовская группа, кург. 4 (по: [Мошкова, Максименко, 1974, табл. XXV,1-3]); 2 - Северо-Западный I, кург. 1, погр. 3 (по: [Власкин, 2000, рис. 1,4]); 3 - Кулешовка, кург. 1, погр. 17 (по: [Глебов, 2017, рис. 4,6); 4 - Кулешовка, кург. 1, погр. 29А (по: [Глебов, 2017, рис. 5,1); 5 - Веселый, кург. 2, погр. 6 (по: [Глебов, 2005, рис. 3,1]); 6 - Валовый I, кург. 26, погр. 1 (по: [Беспалый и др., 2007, табл. 78,5]); 7 - Алитуб, кург. 3, погр. 20 (по: [Глебов, 2007, рис. 5,6]); 8 - Подгорненский I, кург. 6, погр. 8 (по: [Глебов, 2007, рис. 5,8]); 9 - Чалтырский XI, кург. 11, погр. 4 (по: [Яценко, 2018, рис. 61]); 10 - Никитин I, кург. 3, погр. 5 (по: [Глебов, 2009, рис. 1,5]);

11 - Ливенцовский VII, кург. 31, погр. 1 (по: [Глебов, 2009, рис. 1,8]); 12 - Валовый I, кург. 40, погр. 3 (по: [Глебов, 2009, рис. 1,1]); 13 - Аюта I, кург. 1, погр. 3 (по: [Глебов, 2009, рис. 1,11])

Fig. 1. Chronological indicators from the Early Sarmatian culture complexes of the Lower Don region of the $2^{\text {nd }}-1^{\text {st }}$ centuries BC.:

$1-1^{\text {st }}$ Veselovskaya group, kurgan 4 (after: [Moshkova, Maksimenko, 1974, tabl. XXV,1-3]); 2 - Severo-Zapadnyy II, kurgan 1, burial 3(after: [Vlaskin, 2000, fig. 1,4]); 3 - Kuleshovka, kurgan 1, burial 17 (after: [Glebov, 2017, fig. 4,6]); 4 - Kuleshovka, kurgan 1, burial 29A (after: [Glebov, 2017, fig. 5,1]); 5 - Veselyy, kurgan 2, burial 6 (after: [Glebov, 2005, fig. 3,1]); 6 - Valovyy I, kurgan 26, burial 1 (after: [Bespaly etc., tabl. 78,5]); 7 - Alitub, kurgan 3, burial 20 (after: [Glebov, 2007, fig. 5,6]); 8 - Podgornenskiy I, kurgan 6, burial 8 (after: [Glebov, 2007, fig. 5,8]); 9 - Chaltyrskiy XI, kurgan 11, burial 4 (after: [Yatsenko, 2018, fig. 61]); 10 - Nikitin I, kurgan 3, burial 5 (after: [Glebov, 2009, fig. 1,5]);

11 - Liventsovskiy VII, kurgan 31, burial 1 (after: [Glebov, 2009, fig. 1,8]); 12 - Valovyy I, kurgan 40, burial 3 (after: [Glebov, 2009, fig. 1,1]); 13 - Ayuta I, kurgan 1, burial 3 (after: [Glebov, 2009, fig. 1,11]) 


\section{СПИСОК ЛИТЕРАТУРЫ}

Абрамова М. П., 1961. Сарматские погребения Дона и Украины // Советская археология. № 1. С. 91-110.

Амброз А. К., 1966. Фибулы юга европейской части СССР II в. до н.э. - IV в. н.э. САИ. Вып. Д1-30. М. : Наука. $112 \mathrm{c}$.

Арсеньева Т. М., Науменко С. А., 2004. Новые данные о фортификации Танаиса // Древности Боспора. Т. 7. М. : ИА РАН. С. 29-73.

Арсеньева Т. М., Науменко С. А., 2006. Оборонительные укрепления Танаиса (по материалам раскопок 20032004 гг.) // Древности Боспора. Т. 10. М. : ИА РАН. С. 18-61.

Арсеньева Т. М., Ильяшенко С. М., Науменко С. А., 2010. Укрепления в центре западной оборонительной линии Танаиса конца III - II в. до н.э. // Проблемы истории, филологии, культуры. № 1. М. ; Магнитогорск ; Новосибирск : ИА РАН. С. 315-323.

Артамонов М. И., 1949. Раскопки курганов на р. Маныч // Советская археология. Вып. ХІ. С. 305-336.

Бернар П., Абдуллаев К., 1997. Номады на границе Бактрии (к вопросу этнической и культурной идентификации) // Российская археология. № 1. С. 68-86.

Беспалый Е. И., Беспалая Н. Е., Раев Б. А., 2007. Древнее население Нижнего Дона. Курганный могильник «Валовый 1». Ростов н/Д : Изд-во ЮНЦ РАН. 186 с.

Берлизов Н. Е., 1996. Сарматы в Предкавказье. Некоторые аспекты исследования // Актуальные проблемы археологии Северного Кавказа (XIX «Крупновские чтения»). М. : ИА РАН, ГИМ. С. 27-31.

Берлизов Н. Е., 2011. Ритмы Сарматии. Савромато-сарматские племена Южной России в VII в. до н.э. - V в. н.э. Ч. І. Краснодар : Изд-во Краснодар. гос. ун-та культуры и искусств : Парабеллум. 320 с.

Берлизов Н. Е., Еременко В. Е., 1998. Латенские импорты в сарматских погребениях Причерноморья: проблема интерпретации // Древности Кубани. Вып. 7. Краснодар : КГИАМЗ. С. 25-33.

Боровкова Л. А., 2001. Царства «Западного края». М. : Крафт+. 356 с.

Буйских С. Б., 1986. Некоторые вопросы пространственно-структурного развития Ольвийской хоры (VI-II вв. до н.э.) // Ольвия и ее округа. Киев : Наукова думка. С. 17-28.

Булатович С. А., 1997. Тира и Нижнее Поднестровье в IV-III вв. до н.э. по данным монетных находок // Никоний и античный мир Северного Причерноморья. Одесса : ИА НАНУ : Одес. археол. музей. C. 223-227.

Вайнберг Б. И., 1992. Памятники скотоводческих племен в левобережном Хорезме // Степная полоса Азиатской части СССР в скифо-сарматское время. Археология СССР. М. : Наука. С. 116-122.

Виноградов Ю. А., Марченко К. К., Рогов Е. Я., 1997. Сарматы и гибель «Великой Скифии» // Вестник древней истории. №3. С. 93-103.

Виноградов Ю. Г., 1997. Херсонесский декрет о «несении Диониса» IOSPE I² 343 и вторжение сарматов в Скифию // Вестник древней истории. № 3. С. 104-124.

Власкин М. В., 2000. Раннесарматские погребения могильника Северо-Западный I / Сарматы и их соседи на Дону. Материалы и исследования по археологии Дона : сб. науч. ст. Вып. 1. Ростов н/Д: Терра. С. 9-26.

Внуков С. Ю., Ефремов Н. В., 2017. Керамические клейма из раскопок городища Кара-Тобе в Северо-Западном Крыму // Крым в эпоху эллинизма: межкультурные процессы по данным новейших археологический исследований : сб. науч. ст. Симферополь : Тарпан. С. 19-120, 279-287.

Габелко О. Л., 2012. Продолжая дискуссию о понтийской царской эре // Studia historica. Вып. XII. С. 61-74.

Гилевич А. М., 1973. Хронология и топография кладов херсонесских монет IV-II вв. до н.э. и некоторые вопросы скифо-херсонесских взаимоотношений // Античные города Северного Причерноморья и варварский мир : крат. тез. докл. к науч. конф. Л. : Изд-во Гос. Эрмитажа. С. 10-11.

Глебов В. П., 2002. Еще раз о проблеме ІІІ в. до н.э. // Боспорский феномен. Погребальные памятники и святилища : материалы междунар. науч. конф. Ч. 2. СПб. : Изд-во Гос. Эрмитажа. С. 186-197.

Глебов В. П., 2004. Хронология раннесарматской и среднесарматской культур Нижнего Подонья // Сарматские культуры Евразии : проблемы региональной хронологии : докл. к 5-й Междунар. конф. «Проблемы сарматской археологии и истории». Краснодар : Изд-во КубГУ. С. 127-133.

Глебов В. П., 2005. О некоторых проблемах хронологии раннесарматской культуры Нижнего Подонья // Нижневолжский археологический вестник. Вып. 7. С. 34-50. 
Глебов В. П., 2007. Специфика становления раннесарматской культуры на Нижнем Дону // Региональные особенности раннесарматской культуры. Материалы семинара Центра изучения истории и культуры сарматов. Вып. ІІ. Волгоград : Изд-во ВолГУ. С. 59-82.

Глебов В. П., 2009. Фибулы раннесарматской культуры Нижнего Подонья // Пятая Кубанская археологическая конференция : материалы конф. Краснодар : Изд-во КубГУ. С. 70-76.

Глебов В. П., 2010. Раннесарматская культура Нижнего Подонья II-І вв. до н.э. : автореф. дис. ... канд. ист. наук. M. 26 c.

Глебов В. П., 2017. Сарматские погребения из кургана 1 могильника у с. Кулешовка (раскопки 1982 г.) // Нижневолжский археологический вестник. Т. 16, № 1. С. 143-161. DOI: http://doi.org/10.15688/ nav.jvolsu.2017.1.9.

Глебов В. П., Ильяшенко С. М., Толочко И. В., 2005. Погребения с оружием эллинистического времени из некрополя Танаиса // Древности Боспора. Т. 8. М. : ИА РАН. С. 52-97.

Глебов В. П., Ильяшенко С. М., 2019. Сарматы и Танаис во II-І вв. до н.э. по археологическим и письменным источникам // Крым в сарматскую эпоху (ІІ в. до н. э. - V в. н.э.). V. Материалы Х Междунар. науч. конф. «Проблемы сарматской археологии и истории». Симферополь : ООО Фирма Салта ЛТД. С. 80-89.

Граков Б. Н., 1939. Материалы по истории Скифии в греческих надписях Балканского полуострова и Малой Азии // Вестник древней истории. № 3. С. 231-312.

Гуцалов С. Ю., 2004. Древние кочевники Южного Приуралья в VII-I вв. до н.э. Уральск : Западно-Казахстанский центр истории и археологии. $136 \mathrm{c}$.

Десятчиков Ю. М., 1973. Сатархи // Вестник древней истории. № 1. С. 131-144.

Егорова Т. В., 2009. Чернолаковая керамика IV-II вв. до н.э. с памятников Северо-Западного Крыма. М. : Изд-во МГУ. 253 с.

Егорова Т. В., 2018. Еще раз об S-видных эллинистических канфарах // Причерноморье в античное и раннесредневековое время : сб. науч. тр., посвящ. 70-летию проф. В.П. Копылова. Ростов н/Д : Юж. федер. ун-т : Археол. о-во «Наследие». С. 510-519.

Егорова Т. В., 2020. Общие тенденции и региональные особенности импорта чернолаковой керамики в Танаисе // Ноmo omnium horarum : сб. ст. в честь 70-летия А. В. Подосинова. М. : Изд-во Ун-та Дмитрия Пожарского. С. 169-188.

Ильяшенко С. М., Арсеньева Т. М., Науменко С. А., 2015. Оборонительные рвы Танаиса во II-I вв. до н.э. // С Митридата дует ветер. Боспор и Причерноморье в античности. К 70-летию В. П. Толстикова. М. : Русский фонд содействия образованию и науке. С. 174-188.

Зайцев Ю. П., 2012. Античная керамика в ритуальных (вотивных) кладах Северного Причерноморья // Древности Северного Причерноморья III-II вв. до н.э. : сб. науч. ст. Тирасполь : Изд-во Приднестров. гос. ун-та им. Т. Г. Шевченко. С. 55-66.

Зайцев Ю. П., 2017. Крепость Ак-Кая в эпоху эллинизма // Крым в эпоху эллинизма. Межкультурные процессы по данным новейших археологических исследований. Симферополь : Тарпан. С. 121-133.

Зайцев Ю. П., Мордвинцева В. И., 2004. Варварские погребения Крыма 2 в. до н.э. - 1 в. н.э. // Сарматские культуры Евразии: проблемы региональной хронологии : докл. к 5-й Междунар. конф. «Проблемы сарматской археологии и истории». Краснодар : Изд-во КубГУ. С. 174-204.

Зуев В. Ю., 1998. Прохоровские курганы в Южном Приуралье и проблема хронологии раннесарматской культуры : автореф. дис. ... канд. ист. наук. СПб. 32 с.

Зуев В. Ю., 2000. Основные проблемы хронологии «раннесарматской» культуры // Раннесарматская культуpa: формирование, развитие, хронология : материалы IV Междунар. конф. «Проблемы сарматской археологии и истории». Вып. 1. Самара : СНЦ РАН. С. 85-104.

Зуев В. Ю., 2013. О появлении сарматов в степях Евразии по археологическим данным // Боспорский феномен : греки и варвары на Евразийском перекрестке : материалы Междунар. науч. конф. СПб. : Нестористория. С. 512-522.

Кац В. И., 1994. Керамические клейма Херсонеса Таврического. Саратов : Изд-во СГУ. 170 с.

Кац В. И., 2007. Греческие керамические клейма эпохи классики и эллинизма (опыт комплексного изучения). Боспорские исследования. Вып. XVIII. Симферополь ; Керчь : Изд-во крым. отд-ния Ин-та востоковедения. $480 \mathrm{c}$. 
Клепиков В. М., 2000. Памятники III в. до н.э. в Нижнем Поволжье // Раннесарматская культура: формирование, развитие, хронология : материалы IV Междунар. конф. «Проблемы сарматской археологии и истории». Вып. 1. Самара : СНЦ РАН. С. 116-124.

Клепиков В. М., Скрипкин А. С., 2002. Хронология раннесарматских памятников Нижнего Поволжья // Нижневолжский археологический вестник. Вып. 5. С. 47-81.

Коваленко С. А., 2002. О структуре и динамике импорта позднеэллинистической рельефной керамики в Северное Причерноморье // Археологія. № 3. С. 80-96.

Колтухов С. Г., 1999. Укрепления Крымской Скифии. Симферополь : Сонат. 224 с.

Костенко В. И., 1983. Сарматские памятники Днепро-Донского междуречья III в. до н.э. - середины III в. н.э. Днепропетровск : Изд-во ДнепрГУ. 104 с.

Кропотов В. В., 2010. Фибулы сарматской эпохи. Киев : АДЕФ-Украина. 384 с.

Кропотов В. В., 2016. Сарматские погребальные памятники Степного Крыма // Нижневолжский археологический вестник. Т. 15, № 1. С. 22-39. DOI: http://doi.org/10.15688/nav.jvolsu.2016.1.2.

Кропотов В. В., 2019. К проблеме выделения раннесарматских памятников Северного Причерноморья // Крым в сарматскую эпоху (II в. до н.э. - V в. н.э.). V. Материалы Х Междунар. науч. конф. «Проблемы сарматской археологии и истории». Симферополь : ООО Фирма Салта ЛТД. С. 154-160.

Кропотов В. В., Лесков А. М., 2006. Курган с «коллективным погребением» у с. Кринички (по материалам работ 1957 г.) // Культура народов Причерноморья. № 84. Симферополь : Межвузовский центр «Крым». C. $25-39$.

Крыжицкий С. Д., Лейпунская Н. А., 1988. Комплекс западных ворот Ольвии // Античные древности Северного Причерноморья. Киев : Наукова думка. С. 10-32.

Лимберис Н. Ю., Марченко И. И., 2017. Атрибуция и хронология чернолаковых канфаров из меотских памятников Прикубанья // Stratum plus. № 3. С. 181-198.

Максименко В. Е., 1983. Савроматы и сарматы на Нижнем Дону. Ростов н/Д : Изд-во РГУ. 224 с.

Максименко В. Е., 1997. Начало проникновения сарматов в Северное Причерноморье и завоевание Скифии // Донские древности. Вып. 5. Сарматы и Скифия : сб. науч. докл. III Междунар. конф. «Проблемы сарматской археологии и истории». Азов : Азов. краевед. музей. С. 41-49.

Максименко В. Е., 2000. О времени и путях проникновения племен прохоровской культуры в Подонье - Приазовье // Раннесарматская культура: формирование, развитие, хронология : материалы IV Междунар. конф. «Проблемы сарматской археологии и истории». Вып. 2. Самара : СНЦ РАН. C. $158-169$.

Мандельштам А. М., 1992. Кочевое население Среднеазиатского междуречья в последние века до н.э. и первые века н.э. // Степная полоса Азиатской части СССР в скифо-сарматское время. Археология СССР. М. : Наука. С. 107-115.

Мамонтов В. И., 2000. Древнее население левобережья Дона (по материалам курганного могильника Первомайский VII). Волгоград : Изд-во ВолГУ. 194 с.

Марченко И. И., 1996. Сираки Кубани. Краснодар : Изд-во КубГУ. 336 с.

Масленников А. А., 1995. Древние греки в Крымском Приазовье // Вестник древней истории. № 2. С. 78-93.

Масленников А. А., 1999. Греки и варвары на «границах» Боспора : (Взгляд на проблему к концу тысячелетия) // Древнейшие государства Восточной Европы. 1996-1997 гг. Северное Причерноморье в античности : Вопросы источниковедения. М. : Восточная литература. С. 170-192.

Мачинский Д. А., 1971. О времени первого активного выступления сарматов в Поднепровье по свидетельствам античных письменных источников // Археологический сборник Государственного Эрмитажа. Вып. 13. Л. : Изд-во Гос. Эрмитажа. С. 30-54.

Михлин Б. Ю., 1980. Фибулы Беляусского могильника // Советская археология. № 3. С. 194-213.

Мошкова М. Г., Максименко В. Е., 1974. Работы Багаевской экспедиции в 1971 г. // Археологические памятники Нижнего Подонья. Ч. ІІ. М. : Наука С. 5-80.

Никитский А. В., 1894/95. Дельфийские эпиграфические этюды. I-VI. Одесса : Тип. Штаба Округа. 368 с.

Обельченко О. В., 1992. Культура античного Согда. По археологическим данным VII в. до н.э. - VII в. н.э. М. : Наука. $256 \mathrm{c}$. 
Паль Е. П., 2018. Охранно-спасательные археологические исследования ООО Инженерно-технический центр специальных работ и экспертиз на Кубани (2015-2016 гг.) // Материалы и исследования по археологии Северного Кавказа. Вып. 16. Армавир ; Краснодар : НАО «Наследие Кубани». С. 253-281.

Полин С. В., 1992. От Скифии к Сарматии. Киев : ИА АНУ. 201 с.

Полин С. В., 2018. Сарматское завоевание Северного Причерноморья (современное состояние проблемы) // Древности. Исследования. Проблемы : сб. ст. в честь 70-летия Н. П. Тельнова. Кишинев ; Тирасполь : Stratum plus. С. 267-288.

Полин С. В., Симоненко А. В., 1997. Скифия и сарматы // Донские древности. Вып. 5. Сарматы и Скифия : сб. науч. докл. III Междунар. конф. «Проблемы сарматской археологии и истории». Азов : Азов. краевед. музей. С. 87-98.

Самойлова Т. Л., 1988. Тира в VI-І вв. до н.э. Киев : Наукова думка. 119 с.

Симоненко О. В., 1994. Ранньосарматський період у Північному Причорномор’ї// Археологія. № 1. С. $32-48$.

Симоненко А. В., 2001. Европейские аланы и аланы-танаиты в Северном Причерноморье // Российская археология. № 4. С. 77-91.

Симоненко А. В., 2004. Хронология и периодизация сарматских памятников Северного Причерноморья // Сарматские культуры Евразии: проблемы региональной хронологии : докл. к 5-й Междунар. конф. «Проблемы сарматской археологии и истории». Краснодар : Изд-во КубГУ. С. 134-173.

Симоненко А. В., 2007. Мечи и кинжалы прохоровского типа на территории Украины // Вооружение сарматов. Региональная типология и хронология : докл. к VI Междунар. конф. «Проблемы сарматской археологии и истории». Челябинск : Изд-во Юж.-Урал. гос. ун-та. С. 99-113.

Симоненко А. В., 2013. Римский и провинциальный импорт у сарматов Северного Причерноморья. Типология и хронология. Берлин : Palmarium Academic Publishing. 369 с.

Симоненко А. В., 2019. Раннесарматские памятники Орель-Самарского междуречья // Нижневолжский археологический вестник. Т. 18, № 1. C. 81-96. DOI: https://doi.org/10.15688/nav.jvolsu.2019.1.7.

Скрипкин А. С., 2000. Новые аспекты в изучении истории материальной культуры сарматов // Нижневолжский археологический вестник. Вып. 3. С. 17-40.

Скрипкин А. С., 2017. Сарматы. Волгоград : Изд-во ВолГУ. 293 с.

Скрипкин А. С., Клепиков В. М., 2004. Хронология раннесарматской культуры Нижнего Поволжья // Сарматские культуры Евразии: проблемы региональной хронологии : докл. к 5-й Междунар. конф. «Проблемы сарматской археологии и истории». Краснодар : Изд-во КубГУ. С. 95-106.

Смирнов К. Ф., 1984. Сарматы и утверждение их политического господства в Скифии. М. : Наука. 184 с.

Федосеев Н. Ф., 2017. Керамические клейма поселения «Полянка» в Восточном Крыму // Крым в эпоху эллинизма: межкультурные процессы по данным новейших археологический исследований : сб. науч. ст. Симферополь : Тарпан. С. 169-250.

Федоров В. К., 2013. Кинжал из Талалаевки и савроматские элементы в оформлении рукоятей прохоровских клинков // Нижневолжский археологический вестник. Вып. 13. С. 33-47.

Федоров В. К., 2018. Вторжения в могилы единоплеменников при совершении новых захоронений у ранних кочевников Южного Урала VI-I вв. до н.э. // Древние некрополи - погребально-поминальная обрядность, погребальная архитектура и планировка некрополей. Труды ИИМКРАН. Т. 47. СПб. : ИИМК РАН : Гос. Эрмитаж. С. 181-191.

Циркунова И. В., 2008. Чернолаковый канфар из западного пригорода Танаиса // Novensia. Т. 18-19. С. 381-385.

Шевченко Н. Ф., 2011. Степи Прикубанья и сираки в IV-III вв. до н.э. // Историко-археологический альманах. Вып. 10. Армавир ; Краснодар ; М. : ИА РАН : Армавирский краеведческий музей. С. 44-57.

Шевченко Н. Ф., 2013. Племена Восточного Приазовья на рубеже эры. Ростов н/Д : Альтаир. 152 с.

Шелов Д. Б., 1970. Танаис и Нижний Дон в III-І вв. до н.э. М. : Наука. 252 с.

Шелов Д. Б., 1975. Керамические клейма из Танаиса III-I вв. до н.э. М. : Наука. 167 с.

Щеглов А. Н., 1978. Северо-Западный Крым в античную эпоху. Л. : Наука. 158 с.

Щукин М. Б., 1994. На рубеже эр. СПб. : Фарн. 324 с.

Яценко В. В., 2018. Отчет о раскопках курганов 11, 14, 15, 16 «Курганной группы “Чалтырский ХІ” и курганов 2, 3, 4 “Курганной группы “Мокро-Чалтырский I”» в 2015 г. в Мясниковском р-не Ростовской области // Архив ООО АНИБ. № 118. 
Anderson-Stojanovic V. R., 1987. The Chronology and Function of Ceramic Unguentaria // American Journal of Archaeology. Vol. 91, № 1. P. 105-122.

Avram A., 2007. Some Thoughts about the Black Sea and the Slave Trade before the Roman Domination $\left(6^{\text {th }}-\right.$ $1^{\text {st }}$ centuries BC) // The Black Sea in Antiquity : Regional and Interregional Exchanges. Aarhus : Aarhus University Press. P. 239-251.

Bouchon R., Kyriakidis N., 2017. La prêtrise d Apollon Pythien à Delphes, observatoire desdynamiques sociales dans la Grèce sous domination romaine (IIe. s. av. J.-C. - IIe s. apr. J.-C.) // Social dynamics under Roman rule. Mobility and status change in the provinces of Achaia and Macedonia. Meletemata 74. P. 211-240.

Garlan Y., 2004. Les timbres céramiques sinopéens sur amphores et sur tuiles trouvés à Sinope. Présentation et catalogue. Avec la collaboration de H. Kara. Varia Anatolica XVI, Corpus international des timbres amphoriques 10. Paris : Institut français détudes anatoliennes Georges Dumézil, De Boccard. 310 p.

Daux G., 1943. Chronologie delphique (supplément au tome III des Fouilles de Delphes). Paris : E. de Boccard. 131 p.

Finkielsztejn G., 2001. Chronologie detaillee et revisee des eponyms amphoriques rhodiens de 270 a 108 av. J.-C. environ. Premier bilan. BAR International Series 990. Oxford : Archaeopress. 260 p.

Mulliez D., 1998. La chronologie de la prêtrise IV (170/69-158/7) et la date de la mort d'Eumène II // Topoi. Vol. 8/1. P. 231-241.

Mulliez D., 2006. Les fils d'Ariane: quelques questions de chronologie delphique // Comptes rendus des séances de

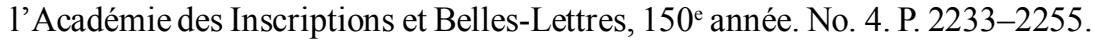

Rotroff S. I., 1997. Hellenistic Pottery: Athenian and Imported Wheelmade Tableware. The Athenian Agora. Vol. XXIX. Part 2 : Illustrations. Princeton : American School of Classical Studies at Athens. 612 p.

Walbank F. W., 1979. A Historical Commentary on Polybius. Vol. III : Commentary on Books XIX-XL. Oxford : The Clarendon Press. XXI +834 p.

\section{REFERENCES}

Abramova M.P., 1961. Sarmatskiye pogrebeniya Dona i Ukrainy [Sarmatian Burials of the Don and Ukraine]. Sovietskaya arkheologiya [Soviet Archaeology], no. 1, pp. 91-110.

Ambroz A.K., 1966. Fibuly yuga yevropeyskoy chasti SSSR II v. do n.e. - IV v. n.e. [Fibulae of the South of the European Part of the USSR, II Century BC - IV Century AD]. Svod Arkheologicheskikh Istochnikov, iss. Д1-30. Moscow, Nauka Publ. 112 p.

Arsenyeva T.M., Naumenko S.A., 2004. Novyye dannyye o fortifikatsii Tanaisa [New Information on the Fortification of Tanais]. Drevnosti Bospora [Antiquities of the Bosporus], vol. 7. Moscow, IA RAS, pp. 29-73.

Arsenyeva T.M., Naumenko S.A., 2006. Oboronitel'nyye ukrepleniya Tanaisa (po materialam raskopok 2003-2004 gg.) [Defensive Fortifications of Tanais (Based on Materials from Excavations in 2003-2004)]. Drevnosti Bospora [Antiquities of the Bosporus], vol. 10. Moscow, IA RAS, pp. 18-61.

Arsenyeva T.M., Il'yashenko S.M., Naumenko S.A., 2010. Ukrepleniya v tsentre zapadnoy oboronitel'noy linii Tanaisa kontsa III - II v. do n.e. [Fortification in the Center of Tanais Western Defenses of the Late $3^{\text {rd }}-$ $2^{\text {nd }}$ CC. B.C.]. Problemy istorii, filologii, kul'tury [Problems of History, Philology, and Culture], no. 1, Moscow, Magnitogorsk, Novosibirsk, IA RAS, pp. 315-323.

Artamonov M.I., 1949. Raskopki kurganov na r. Manych [Excavation of Burial Mounds on the River Manych]. Sovietskaya arkheologiya [Soviet Archaeology], iss. XI, pp. 305-336.

Bernar P., Abdullaev K., 1997. Nomady na granitse Baktrii (k voprosu etnicheskoy i kul'turnoy identifikatsii) [Nomads on the Bactrian Border (on the Issue of Ethnic and Cultural Identification)]. Rossiyskaya arkheologiya [Russian Archaeology], no. 1, pp. 68-86.

Bespaly E.I., Bespalaya N.E., Raev B.A., 2007. Drevneye naseleniye Nizhnego Dona. Kurgannyy mogil'nik "Valovyy 1» [Ancient Population of the Lower Don. Burial Mound "Valovy 1"]. Rostov-on-Don, SSC RAS. $186 \mathrm{p}$.

Berlizov N.E., 1996. Sarmaty v Predkavkaz'ye. Nekotoryye aspekty issledovaniya [Sarmatians in the Ciscaucasia. Some Aspects of Research]. Aktual'nyye problemy arkheologii Severnogo Kavkaza (XIX «Krupnovskiye chteniya») [Actual Problems of Archaeology of the North Caucasus (XIX “Krupnovskie Readings")]. Moscow, IA RAS, SHM, pp. 27-31. 
Berlizov N.E., 2011. Ritmy Sarmatii. Savromato-sarmatskiye plemena Yuzhnoy Rossii v VII v. do n.e. - V v. n.e. Chast' 1 [Rhythms of Sarmatia. The Sauromato-Sarmatian Tribes of Southern Russia in the VII Century BC V Century AD. Part I]. Krasnodar, Krasnodar State University of Culture and Arts, Parabellum Publ. 320 p.

Berlizov N.E., Eremenko V.E., 1998. Latenskiye importy v sarmatskikh pogrebeniyakh Prichernomor'ya: problema interpretatsii [Laten Imports in Sarmatian Burials of the Black Sea Region: the Problem of Interpretation]. Drevnosti Kubani [Antiquities of the Kuban], iss. 7. Krasnodar, KSHAMR, pp. 25-33.

Borovkova L.A., 2001. Tsarstva «Zapadnogo kraya» [Kingdoms of the "Western Territory"]. Moscow, Kraft+ Publ. 356 p.

Buiskikh S.B., 1986. Nekotoryye voprosy prostranstvenno-strukturnogo razvitiya Ol'viyskoy khory (VI-II vv. do n.e.). [Some Questions of Spatial and Structural Development of the Olbian Hora (VI-II Centuries BC)]. Ol'viya $i$ yeyo okruga [Olbia and its Districts]. Kiev, Naukova dumka Publ., pp. 17-28.

Bulatovich S.A., 1997. Tira i Nizhneye Podnestrov'ye v IV-III vv. do n.e. po dannym monetnykh nakhodok [Tira and Lower Dniester in the IV-III Centuries BC According to Coin Finds]. Nikoniy i antichnyy mir Severnogo Prichernomor'ya [Nikoniy and the Ancient World of the Northern Black Sea Region]. Odessa, IA ASU, OAM, pp. 223-227.

Vaynberg B. I., 1992. Pamyatniki skotovodcheskikh plemon v levoberezhnom Khorezme [Monuments of Cattle Breeding Tribes in the Left-Bank Khorezm]. Stepnaya polosa Aziatskoy chasti SSSR v skifo-sarmatskoye vremya [The Steppe Zone of the Asian Part of the USSR in the Scythian-Sarmatian Time]. Moscow, Nauka Publ., pp. 116-122.

Vinogradov Yu.A., Marchenko K.K., Rogov E.Ya., 1997. Sarmaty i gibel' «Velikoy Skifii» [Sarmatians and the Death of the "Great Scythia"]. Vestnik drevney istorii [Journal of Ancient History], no. 3, pp. 93-103.

Vinogradov Yu.G., 1997. Khersonesskiy dekret o «nesenii Dionisa» IOSPE I² 343 i vtorzheniye sarmatov v Skifiyu [Chersonesus Decree on "Carrying Dionysus" IOSPE I² 343 and the Sarmatian Invasion of Scythia]. Vestnik drevney istorii [Journal of Ancient History], no. 3, pp. 104-124.

Vlaskin M.V., 2000. Rannesarmatskiye pogrebeniya mogil'nika Severo-Zapadnyy I [Early Sarmatian Burials of the Burial Ground Severo-Zapadny I]. Sarmati $i$ ih sosedi na Dony. Materialy i issledovaniya po archeologii Dona: sb. nauch. st. [Sarmatians and their Neighbors on the Don. Materials and Research on the Archaeology of the Don. Collection of Scientific Articles], iss. 1. Rostov-na-Donu, Terra Publ., pp. 9-26.

Vnukov S.Yu., Yefremov N.V., 2017. Keramicheskiye kleyma iz raskopok gorodishcha Kara-Tobe v Severo-Zapadnom Krymu [Ceramic Stamps from the Excavations of the Settlement Kara-Tobe in the North-Western Crimea]. Krym v epokhu ellinizma: mezhkul'turnyye protsessy po dannym noveyshikh arkheologicheskikh issledovaniy: sb. nauch. st. [Crimea in the Era of Hellenism. Intercultural Processes According to the Latest Archaeological Research. Collection of Scientific Articles]. Simferopol', Tarpan Publ., pp. 19-120, 279-287.

Gabelko O.L., 2012. Prodolzhaya diskussiyu o pontiyskoy tsarskoy ere [Continuing the Discussion About the Pontic Royal Era]. Studia historica, iss. XII. Moscow, pp. 61-74.

Gilevich A.M., 1973. Khronologiya i topografiya kladov khersonesskikh monet IV-II vv. do n.e. i nekotoryye voprosy skifo-khersonesskikh vzaimootnosheniy [Chronology and Topography of the Treasures of Chersonesos Coins of the IV-II Centuries BC and Some Questions of the Scythian-Chersonesus Relationship]. Antichnyye goroda Severnogo Prichernomor'ya i varvarskiy mir: krat. tez. dokl. k nauch. konf. [Antique Cities of the Northern Black Sea Region and the Barbarian World. Brief Theses of Reports for the Scientific Conference]. Leningrad, State Hermitage Museum, pp. 10-11.

Glebov V.P., 2002. Yeshche raz o probleme III v. do n.e. [Once Again About the Problem of the III Century BC]. Bosporskiy fenomen. Pogrebal'nyye pamyatniki i svyatilishcha: materialy mezhdunar. nauch. konf. [Bosporan Phenomenon. Funeral Monuments and Sanctuaries: Materials of the International Scientific Conference], part 2. Saint Petersburg, State Hermitage Museum, pp. 186-197.

Glebov V.P., 2004. Khronologiya rannesarmatskoy i srednesarmatskoy kul'tur Nizhnego Podon'ya [Chronology of the Early Sarmatian and Middle Sarmatian Cultures of the Lower Don Region]. Sarmatskiye kul 'tury Yevrazii: problemy regional'noy khronologii: dokl. $k$ 5-y Mezhdunar. konf. «Problemy sarmatskoy arkheologii $i$ istorii» [Sarmatian Cultures of Eurasia: Problems of Regional Chronology. Reports for the $5^{\text {th }}$ International Conference "Problems of Sarmatian Archaeology and History"]. Krasnodar, KSU, pp. 127-133.

Glebov V.P., 2005. O nekotorykh problemakh khronologii rannesarmatskoy kul'tury Nizhnego Podon'ya [About Some Problems of Chronology of the Early Sarmatian Culture of the Lower Don Region]. Nizhnevolzhskiy arkheologicheskiy vestnik [The Lower Volga Archaeologocal Bulletin], iss. 7, pp. 34-50. 
Glebov V.P., 2007. Spetsifika stanovleniya rannesarmatskoy kul'tury na Nizhnem Donu [Specificity of the Formation of the Early Sarmatian Culture in the Lower Don]. Regional'nyye osobennosti rannesarmatskoy kul'tury. Materialy seminara Tsentra izucheniya istorii i kul tury sarmatov [Regional Features of the Early Sarmatian Culture. Materials of the Seminar of the Center for the Study of the History and Culture of the Sarmatians], iss. II. Volgograd, VolSU, pp. 59-82.

Glebov V.P., 2009. Fibuly rannesarmatskoy kul'tury Nizhnego Podon'ya [Fibulae of the Early Sarmatian Culture of the Lower Don Region]. Pyataya Kubanskaya arkheologicheskaya konferentsiya: materialy konf. [Fifth Kuban Archaeological Conference. Conference Materials]. Krasnodar, KSU, pp. 70-76.

Glebov V.P., 2010. Rannesarmatskaya kul'tura Nizhnego Podon'ya II-I vv. do n.e.: avtoref. dis. ... kand. ist. nauk [Early Sarmatian Culture of the Lower Donets of the II-I Centuries BC. Cand. hist. sci. abs. diss.]. Moscow. 26 p.

Glebov V.P., 2017. Sarmatskiye pogrebeniya iz kurgana 1 mogil’nika u s. Kuleshovka (raskopki 1982 g.) [Sarmatian Burials from the Barrow 1 of Burial Mound near Kuleshovka Village (Excavations of 1982)]. Nizhnevolzhskiy arkheologicheskiy vestnik [The Lower Volga Archaeological Bulletin], vol. 16, no. 1, pp. 143-161. DOI: http:// doi.org/10.15688/nav.jvolsu.2017.1.9.

Glebov V.P., Ilyashenko S.M., Tolochko I.V., 2005. Pogrebeniya s oruzhiyem ellinisticheskogo vremeni iz nekropolya Tanaisa [Burials with Weapons from the Hellenistic Time from the Necropolis of Tanais]. Drevnosti Bospora [Antiquities of the Bosporus], vol. 8. Moscow, IA RAS, pp. 52-97.

Glebov V.P., Ilyashenko S.M., 2019. Sarmaty i Tanais vo II-I vv. do n.e. po arkheologicheskim i pis'mennym istochnikam [Sarmatians and Tanais in the Second and First Centuries BC According to Archaeological and Written Sources]. Krym v sarmatskuyu epokhu (II v. do n.e. - V v. n.e.). V. Materialy X Mezhdunar. nauch. konf. «Problemy sarmatskoy arkheologii i istorii» [Crimea in the Sarmatian Era (II Century BC - V Century AD). Materials of the X International Scientific Conference "Problems of Sarmatian Archaeology and History"]. Simferopol', OOO Firma Salta LTD Publ., pp. 80-89.

Grakov B.N., 1939. Materialy po istorii Skifii v grecheskikh nadpisyakh Balkanskogo poluostrova i Maloy Azii [Materials on the History of Scythia in the Greek Inscriptions of the Balkan Peninsula and Asia Minor]. Vestnik drevney istorii [Journal of Ancient History], no. 3, pp. 231-312.

Gutsalov S.Yu., 2004. Drevniye kochevniki Yuzhnogo Priural'ya v VII-I vv. do n.e. [Ancient Nomads of the Southern Urals in the VII-I Centuries BC]. Ural'sk, West Kazakhstan center of history and archaeology. $136 \mathrm{p}$.

Desyatchikov Yu.M., 1973. Satarhi [Satarkhi]. Vestnik drevney istorii [Journal of Ancient History], no. 1, pp. 131-144.

Egorova T.V., 2009. Chernolakovaya keramika IV-II vv. do n.e. s pamyatnikov Severo-Zapadnogo Kryma [BlackLacquered Ceramics of the IV-II Centuries BC from the Monuments of the North-Western Crimea]. Moscow, MSU. 253 p.

Egorova T.V., 2018. Yeshche raz ob S-vidnykh ellinisticheskikh kanfarakh [Once Again About the S-Prominent Hellenistic Canfars]. Prichernomor'ye $v$ Antichnoye $i$ rannesrednevekovoye vremya: sb. nauch. tr., posvyashch. 70-letiyu professora V.P. Kopylova [Black Sea Region in Antique and Early Medieval Times. Collection of Scientific Papers Dedicated to the $70^{\text {th }}$ Anniversary of Professor V.P. Kopylov]. Rostov-on-Don, SFU, Archaeological Society “Heritage”, pp. 510-519.

Egorova T.V., 2020. Obshchiye tendentsii i regional'nyye osobennosti importa chernolakovoy keramiki v Tanaise [General Trends and Regional Characteristics of the Import of Black Glazed Pottery in Tanais]. Homo omnium horarum: sb. st. v chest'70-letiya A.V. Podosinova [Homo Omnium Horarum. Collection of Articles in Honor of the $70^{\text {th }}$ Anniversary of A.V. Podosinova]. Moscow, University of Dmitry Pozharsky, pp. 169-188.

Ilyashenko S.M., Arsenyeva T.M., Naumenko S.A., 2015. Oboronitel'nyye rvy Tanaisa vo II- I vv. do n.e. [Defensive Ditches of Tanais in the $2^{\text {nd }-1} 1^{\text {st }}$ Centuries BC]. S Mitridata duyet veter. Bospor i Prichernomor'ye vantichnosti. K 70-letiyu V.P. Tolstikova [Wind Blows Down the Mount Mithridates. The Bosporos and the Black Sea in Antiquity. Studies Presented to V.P. Tolstikov on the Occasion of his $70^{\text {th }}$ Birthday]. Moscow, Russian Foundation for the Promotion of Education and Science, pp. 174-188.

Zaitsev Yu.P., 2012. Antichnaya keramika v ritual'nykh (votivnykh) kladakh Severnogo Prichernomor'ya [Ancient Ceramics in Ritual (Votive) Hoards of the Northern Black Sea Region]. Drevnosti Severnogo Prichernomor'ya III-II vv. do n.e.: sb. nauch. st. [Antiquities of the Northern Black Sea Region of the III-II Centuries BC. Collection of Scientific Articles]. Tiraspol', Pridnestrovian State University, pp. 55-66.

Zaitsev Yu.P., 2017. Krepost' Ak-Kaya v epokhu ellinizma [The Fortress Ак-Kaya in the Hellenistic Period Research]. Krym v epokhu ellinizma. Mezhkul'turnyye protsessy po dannym noveyshikh arkheologicheskikh 
issledovaniy [Crimea in the Era of Hellenism. Intercultural Processes According to the Latest Archaeological Research]. Simferopol', Tarpan Publ., pp. 121-133.

Zaitsev Yu.P., Mordvintseva V.I., 2004. Varvarskiye pogrebeniya Kryma 2 v. do n.e. - 1 v. n.e. [Barbarian Burials of the Crimea 2 Century BC - 1 Century AD]. Sarmatskiye kul tury Yevrazii: problemy regional'noy khronologii: dokl. k 5-y Mezhdunar. konf. «Problemy sarmatskoy arkheologii i istorii» [Sarmatian Cultures of Eurasia: Problems of Regional Chronology. Reports for the $5^{\text {th }}$ International Conference "Problems of Sarmatian Archaeology and History"]. Krasnodar, KubSU, pp. 174-204.

Zuev V.Yu., 1998. Prokhorovskiye kurgany v Yuzhnom Priural'ye i problema khronologii rannesarmatskoy kul 'tury: avtoref. dis. ... kand. ist. nauk [Prokhorov Kurgans in the Southern Urals and the Problem of the Chronology of the Early Sarmatian Culture. Cand. hist. sci. abs. diss.]. Saint Petersburg. 32 p.

Zuev V.Yu., 2000. Osnovnyye problemy khronologii «rannesarmatskoy» kul'tury [The Main Problems of the Chronology of the "Early Sarmatian" Culture]. Rannesarmatskaya kul'tura: formirovaniye, razvitiye, khronologiya: materialy IV Mezhdunar. konf. "Problemy sarmatskoy arkheologii i istorii» [Materials of the IV International Conference "Problems of Sarmatian Archaeology and History"], iss. 1. Samara, SSC RAS, pp. 85-104.

Zuev V.Yu., 2013. O poyavlenii sarmatov v stepyakh Yevrazii po arkheologicheskim dannym [About the Appearance of Sarmatians in the Steppes of Eurasia According to Archaeological Data]. Bosporskiy fenomen: greki $i$ varvary na Yevraziyskom perekrestke: materialy Mezhdunar. nauch. konf. [The Bosporan Phenomenon: Greeks and Barbarians at the Eurasian Crossroads: Materials of the International Scientific Conference]. Saint Petersburg, Nestor-istoriya Publ., pp. 512-522.

Kats V.I., 1994. Keramicheskiye kleyma Khersonesa Tavricheskogo [Ceramic Stamps of Tauric Chersonesos]. Saratov, SSU. 170 p.

Kats V.I., 2007. Grecheskiye keramicheskiye kleyma epokhi klassiki i ellinizma (opyt kompleksnogo izucheniya). Bosporskiye issledovaniya [Greek Ceramic Stamps of the Classical and Hellenistic Era (Experience of Complex Study). Bosporan Research], iss. XVIII. Simferopol', Kerch', Crimean branch of the Institute of Oriental Studies. $480 \mathrm{p}$.

Klepikov V.M., 2000. Pamyatniki III v. do n.e. v Nizhnem Povolzh'ye [Monuments of the III Century BC in the Lower Volga Region]. Rannesarmatskaya kul'tura: formirovaniye, razvitiye, khronologiya: materialy IV Mezhdunar. konf. «Problemy sarmatskoy arkheologii i istorii» [Materials of the IV International Conference "Problems of Sarmatian Archaeology and History"], iss. 1. Samara, SSC RAS, pp. 116-124.

Klepikov V.M., Skripkin A.S., 2002. Khronologiya rannesarmatskikh pamyatnikov Nizhnego Povolzh'ya [Chronology of the Early Sarmatian Monuments in the Lower Volga Area]. Nizhnevolzhskiy arkheologicheskiy vestnik [The Lower Volga Archaeologocal Bulletin], iss. 5, pp. 47-81.

Kovalenko S.A., 2002. O strukture i dinamike importa pozdneellinisticheskoy rel'yefnoy keramiki v Severnoye Prichernomor'ye [About Structure and Dynamics of the Import of Late Hellenistic Relief Pottery in the Northern Black Sea Region]. Arkheologiya [Archaeology], no. 3, pp. 80-96.

Koltukhov S.G., 1999. Ukrepleniya Krymskoy Skifii [Fortifications of the Crimean Scythia]. Simferopol, Sonat Publ. 224 p.

Kostenko V.I., 1983. Sarmatskiye pamyatniki Dnepro-Donskogo mezhdurechia III v. do n.e. - serediny III v. n.e. [Sarmatian Monuments of the Dnieper-Don Interfluve III Century BC-Mid-Third Century BC]. Dnepropetrovsk, Izd-vo DneprGU. 104 p.

Kropotov V.V., 2010. Fibuly sarmatskoy epokhi [Fibulae of the Sarmatian Epoch]. Kiev, ADEF-Ukraine Publ. 384 p.

Kropotov V.V., 2016. Sarmatskiye pogrebal'nyye pamyatniki Stepnogo Kryma [Sarmatian Burial Monuments of the Steppe Crimea]. Nizhnevolzhskiy arkheologicheskiy vestnik [The Lower Volga Archaeological Bulletin], vol. 15, no. 1, pp. 22-39. DOI: http://doi.org/10.15688/nav.jvolsu.2016.1.2.

Kropotov V.V., 2019. K probleme vydeleniya rannesarmatskikh pamyatnikov Severnogo Prichernomor'ya [On the Problem of Identifying Early Sarmatian Monuments of the Northern Black Sea Region]. Krym v sarmatskuyu epokhu (II v. do n.e. - V v. n.e.). V. Materialy X Mezhdunar. nauch. konf. «Problemy sarmatskoy arkheologii $i$ istorii» [Crimea in the Sarmatian Era (II Century BC - V Century AD). V. Materials of the X International Scientific Conference "Problems of Sarmatian Archaeology and History"]. Simferopol', OOO Firma Salta LTD Publ., pp. 154-160.

Kropotov V.V., Leskov A.M., 2006. Kurgan s «kollektivnym pogrebeniyem» u s. Krinichki (po materialam rabot 1957 g.) [The Burial Mound with "Collective Burial” Near Village Krynichki (Based on the Works of 1957)]. 
Kul 'tura narodov Prichernomor'ya [Culture of the Peoples of the Black Sea Region], no. 84. Simferopol', Interuniversity Center "Crimea” Publ., pp. 25-39.

Kryzhitsky S.D., Leypunskaya N.A., 1988. Kompleks zapadnykh vorot Ol'vii [The Complex of the Western Gate of Olbia]. Antichnyye drevnosti Severnogo Prichernomor'ya [Antique Antiquities of the Northern Black Sea region]. Kiev, Naukova dumka Publ., pp. 10-32.

Limberis N.Yu., Marchenko I.I., 2017. Atributsiya i khronologiya chernolakovykh kanfarov iz meotskikh pamyatnikov Prikuban'ya [Attribution and Chronology of Black Lacquer Canfars from Meotian Monuments of the Kuban Area]. Stratum plus, no. 3, pp. 181-198.

Maksimenko V.E., 1983. Savromaty i sarmaty na Nizhnem Donu [Savromats and Sarmatians in the Lower Don]. Rostov-on-Don, Rostov State University. 224 p.

Maksimenko V.E., 1997. Nachalo proniknoveniya sarmatov v Severnoye Prichernomor'ye i zavoyevaniye Skifii [The Beginning of the Penetration of the Sarmatians into the Northern Black Sea Region and the Conquest of Scythia]. Donskie drevnosti. Vyp. 5. Sarmaty i Skifiya: sb. nauch. dokl. III Mezhdunar. konf. «Problemy sarmatskoy arkheologii i istorii» [Don Antiquities. Iss. 5: Sarmatians and Scythia: Collection of Scientific Reports. $3^{\text {rd }}$ International Conference "Problems of Sarmatian Archaeology and History"]. Azov, Azov Regional Museum, pp. 41-49.

Maksimenko V.E., 2000. O vremeni i putyakh proniknoveniya plemen prokhorovskoy kul'tury v Podon'ye - Priazov'ye [About the Time and Ways of Penetration of the Tribes of the Prokhorovka Culture in the Don - Azov Region]. Rannesarmatskaya kul'tura: formirovaniye, razvitiye, khronologiya: materialy IV Mezhdunar. konf. «Problemy sarmatskoy arkheologii i istorii» [Materials of the IV International Conference "Problems of Sarmatian Archaeology and History"], iss. 2. Samara, SSC RAS, pp. 158-169.

Mandelstam A.M., 1992. Kochevoye naseleniye Sredneaziatskogo mezhdurech'ya v posledniye veka do n.e. i pervyye veka n.e. [The Nomadic Population of the Central Asian Interfluve in the Last Centuries BC and the First Centuries AD]. Stepnaya polosa Aziatskoy chasti SSSR v skifo-sarmatskoye vremya. Arkheologiya SSSR [The Steppe Zone of the Asian Part of the USSR in the Scythian-Sarmatian Time. Archaeology of the USSR]. Moscow, Nauka Publ., pp. 107-115.

Mamontov V.I., 2000. Drevnee naselenie levoberezh'ya Dona (po materialam kurgannogo mogil'nika Pervomayskiy VII) [Ancient Population of the Left Bank of the Don (Based on Materials from the Pervomaisky VII Kurgan Cemetery)]. Volgograd, VolSU. 194 p.

Marchenko I.I., 1996. Siraki Kubani [Siraki Kuban]. Krasnodar, KubSU. 336 p.

Maslennikov A.A., 1995. Drevniye greki v Krymskom Priazov’ye [Ancient Greeks in the Crimean Azov Region]. Vestnik drevney istorii [Journal of Ancient History], no. 2, pp. 78-93.

Maslennikov A.A., 1999. Greki i varvary na «granitsakh» Bospora: (Vzglyad na problemu k kontsu tysyacheletiya) [Greeks and Barbarians on the "Borders" of the Bosporus (A Look at the Problem by the End of the Millennium)]. Drevneyshiiye gosudarstva Vostochnoy Yevropy. 1996-1997 gg. Severnoye Prichernomor'ye v antichnosti: Voprosy istochnikovedeniya [The Most Ancient States of Eastern Europe. 1996-1997. Northern Black Sea Region in Antiquity: Questions of Source Study]. Moscow, Vostochnaya literatura Publ., pp. 170-192.

Machinskiy D.A., 1971. O vremeni pervogo aktivnogo vystupleniya sarmatov v Podneprovye po svidetelstvam antichnykh pismennykh istochnikov [About the Time of the First Active Attack of Sarmatians in the Dnieper According to the Ancient Written Sources]. Arkheologicheskiy sbornik Gosudarstvennogo Ermitazha [Archaeological Papers of the State Hermitage Museum], iss. 13. Leningrad, State Hermitage Publ., pp. 30-54.

Mikhlin B.Yu., 1980. Fibuly Belyausskogo mogil'nika [Fibulae of the Belyaussky Burial Ground]. Sovietskaya arkheologiya [Soviet Archaeology], no. 3, pp. 194-213.

Moshkova M.G., Maksimenko V.E., 1974. Raboty Bagayevskoy ekspeditsii v 1971 g. [Works of the Bagaevsky Expedition in 1971]. Arkheologicheskiye pamyatniki Nizhnego Podon'ya [Archaeological Monuments of the Lower Don Region], part II. Moscow, Nauka Publ., pp. 5-80.

Nikitskiy A.V., 1894/95. Del'fiyskiye epigraficheskiye etyudy [Delphic Epigraphic Studies]. I-VI. Odessa. 368 p.

Obel'chenko O.V., 1992. Kul'tura antichnogo Sogda. Po arkheologicheskim dannym VII v. do n.e. - VII v. n.e. [The Culture of Ancient Sogd. According to Archaeological Data of the VII Century BC - VII Century AD]. Moscow, Nauka Publ. 256 p.

Pal E.P., 2018. Okhranno-spasatel'nyye arkheologicheskiye issledovaniya OOO Inzhenerno-tekhnicheskiy tsentr spetsial'nykh rabot i ekspertiz na Kubani (2015-2016 gg.) [Security-Rescue Archeological Researches of 
OOO "Engineering-Technical Center of Special Works and Expertise" in Kuban (2015-2016)]. Materialy $i$ issledovaniya po arkheologii Severnogo Kavkaza [Materials and Research on the Archaeology of the North Caucasus], iss. 16. Armavir, Krasnodar, NJC "Heritage of the Kuban”, pp. 253-281.

Polin S.V., 1992. Ot Skifii k Sarmatii [From Scythia to Sarmatia]. Kiev, IAASU. 201 p.

Polin S.V., 2018. Sarmatskoe zavoevanie Severnogo Prichernomorya (sovremennoe sostoyanie problemy) [Sarmatian Conquest of the Northern Black Sea Region (Current Studies)]. Drevnosti. Issledovaniya. Problemy: sb. st. $v$ chest 70-letiia N.P. Telnova [Antiquities. Studies. Issues. Collection of Articles in Honor of the $70^{\text {th }}$ Anniversary of N.P. Telnov]. Kishinev, Tiraspol, Stratum Plus, pp. 267-288.

Polin S.V., Simonenko A.V., 1997. Skifiya i sarmaty [Scythia and Sarmatians]. Donskie drevnosti. Vyp. 5. Sarmaty i Skifiya: sb. nauch. dokl. III Mezhdunar. konf. «Problemy sarmatskoy arkheologii i istorii» [Don Antiquities. Iss. 5: Sarmatians and Scythia: Collection of Scientific Reports. $3^{\text {rd }}$ International Conference "Problems of Sarmatian Archaeology and History”]. Azov, Azov Regional Museum, pp. 87-98.

Samoylova T.L., 1988. Tira v VI-I vv. do n.e. [Tira in the VI-I Centuries BC]. Kiev, Naukova dumka Publ. 119 p.

Simonenko O.V., 1994. Rann'osarmat·s'kyy period u Pivnichnomu Prychornomor'yi [Early Sarmatian Period in the Northern Black Sea Region]. Arkheologiya [Archaeology], no. 1, pp. 32-48.

Simonenko A.V., 2001. Yevropeyskiye alany i alany-tanaity v Severnom Prichernomor'ye [European Alans and Alans-Tanaites in the Northern Black Sea Region]. Rossiyskaya arkheologiya [Russian Archaeology], no. 4, pp. 77-91.

SimonenkoA.V., 2004. Khronologiya i periodizatsiya sarmatskikh pamyatnikov Severnogo Prichernomor'ya [Chronology and Periodization of the Sarmatian Monuments of the Northern Black Sea Region]. Sarmatskiye kul tury Yevrazii: problemy regional'noy khronologii: dokl. k 5-y Mezhdunar. konf. «Problemy sarmatskoy arkheologii i istorii» [Sarmatian Cultures of Eurasia: Problems of Regional Chronology. Reports for the $5^{\text {th }}$ International Conference "Problems of Sarmatian Archaeology and History"]. Krasnodar, KubSU, pp. 134-173.

Simonenko A.V., 2007. Mechi i kinzhaly prokhorovskogo tipa na territorii Ukrainy [Swords and Daggers of the Prokhorov Type on the Territory of Ukraine]. Vooruzheniye sarmatov. Regional'naya tipologiya $i$ khronologiya: dokl. k VI Mezhdunar. konf. «Problemy sarmatskoy arkheologii i istorii» [Reports for the VI International Conference "Problems of Sarmatian Archaeology and History"]. Chelyabinsk, SUSU, pp. 99-113.

Simonenko A.V., 2013. Rimskiy i provintsial'nyy import u sarmatov Severnogo Prichernomor'ya. Tipologiya $i$ khronologiya [Roman and Provincial Imports from the Sarmatians of the Northern Black Sea Region. Typology and Chronology]. Berlin, Palmarium Academic Publ. 369 p.

Simonenko A.V., 2019. Rannesarmatskiye pamyatniki Orel'-Samarskogo mezhdurech'ya [Early Sarmatian Monuments of the Orel-Samara Interfluve]. Nizhnevolzhskiy arkheologicheskiy vestnik [The Lower Volga Archaeological Bulletin], vol. 18, no. 1, pp. 81-96. DOI: https://doi.org/10.15688/nav.jvolsu.2019.1.7.

Skripkin A.S., 2000. Novyye aspekty v izuchenii istorii material'noy kul'tury sarmatov [New Aspects in the Investigation of the History of Sarmatian Material Culture]. Nizhnevolzhskiy arkheologicheskiy vestnik [The Lower Volga Archaeologocal Bulletin], iss. 3, pp. 17-40.

Skripkin A.S., 2017. Sarmaty [Sarmatians]. Volgograd, VolSU. 293 p.

Skripkin A.S., Klepikov V.M., 2004. Khronologiya rannesarmatskoy kul'tury Nizhnego Povolzh'ya [Chronology of the Early Sarmatian Culture of the Lower Volga Region]. Sarmatskiye kul 'tury Yevrazii: problemy regional'noy khronologii: dokl. k 5-y Mezhdunar. konf. «Problemy sarmatskoy arkheologii i istorii» [Sarmatian Cultures of Eurasia: Problems of Regional Chronology. Reports for the $5^{\text {th }}$ International Conference "Problems of Sarmatian Archaeology and History”]. Krasnodar, KubSU, pp. 95-106.

Smirnov K.F., 1984. Sarmaty i utverzhdeniye ikh politicheskogo gospodstva v Skifii [Sarmatians and the Assertion of their Political Domination in Scythia]. Moscow, Nauka Publ. 184 p.

Fedoseyev N.F., 2017. Keramicheskiye kleyma poseleniya «Polyanka» v Vostochnom Krymu [Ceramic Stamps of the Settlement "Polyanka" in the Eastern Crimea]. Krym v epokhu ellinizma: mezhkul turnyye protsessy po dannym noveyshikh arkheologicheskikh issledovaniy: sb. nauch. st. [Crimea in the Era of Hellenism. Intercultural Processes According to the Latest Archaeological Research. Collection of Scientific Articles]. Simferopol', Tarpan Publ., pp. 169-250.

Fedorov V.K., 2013. Kinzhal iz Talalayevki i savromatskiye elementy v oformlenii rukoyatey prokhorovskikh klinkov [A Dagger from Talalaevka and "Sauromatic" Elements in the Oramentation of Handles 
of Prokhorovsky Type Blade Weapons]. Nizhnevolzhskiy arkheologicheskiy vestnik [The Lower Volga Archaeologocal Bulletin], iss. 13, pp. 33-47.

Fedorov V.K., 2018. Vtorzheniya v mogily yedinoplemennikov pri sovershenii novykh zakhoroneniy u rannikh kochevnikov Yuzhnogo Urala VI-I vv. do n.e. [Encroaching of Tribe-Mate Graves During the Creation of New Burials Among Nomads of Southern Urals at VI-I Centuries B.C.]. Drevniye nekropoli-pogrebal'nopominal 'naya obryadnost', pogrebal 'naya arkhitektura i planirovka nekropoley. Trudy IIMK RAN [Ancient Necropolises - Funeral and Memorial Ritualism, Architecture and Planning of Necropolises. Proceedings of the IHMK RAS], vol. 47. Saint Petersburg, IHMK RAS, State Hermitage Museum, pp. 181-191.

Tsirkunova I.V., 2008. Chernolakovyy kanfar iz zapadnogo prigoroda Tanaisa [Black-Glazed Canfar from the Western Suburb of Tanais]. Novensia, vol. 18-19, pp. 381-385.

Shevchenko N.F., 2011. Stepi Prikubanya i siraki v VI-III vv. do n.e. [The Steppes of Kuban and the Siraks During VI-III Century BC]. Istoriko-arkheologicheskiy almanakh [Historical and Archaeological Almanac], vol. 10. Armavir, Krasnodar, Moscow, IA RAS, Armavir Regional Museum, pp. 44-57.

Shevchenko N.F., 2013. Plemena Vostochnogo Priazov'ya na rubezhe ery [Tribes of the Eastern Azov Region at the Turn of the Era]. Rostov-on-Don, Al'tair Publ. 152 p.

Shelov D.B., 1970. Tanais i Nizhniy Don v III-I vv. do n.e. [Tanais and the Lower Don in the III-I Centuries BC]. Moscow, Nauka Publ. 252 p.

Shelov D.B., 1975. Keramicheskiye kleyma iz Tanaisa III-Ivv. do n.e. [Ceramic Stamps from Tanais III-I Centuries]. Moscow, Nauka Publ. 167 p.

Shcheglov A.N., 1978. Severo-Zapadnyy Krym v antichnuyu epokhu [North-West Crimea in Ancient Times]. Leningrad, Nauka Publ. 158 p.

Shchukin M.B., 1994. Na rubezhe er [At the Turn of the Era]. Saint Petersburg, Farn Publ. 324 p.

Yatsenko V.V., 2018. Otchot o raskopkakh kurganov 11, 14, 15, 16 «Kurgannoy gruppy “Chaltyrskiy XI” i kurganov 2, 3, 4 "Kurgannoy gruppy “Mokro-Chaltyrskiy I"» v 2015 g. v Myasnikovskom r-ne Rostovskoy oblasti [The Report on the Excavation of Kurgans 11, 14, 15, 16 of the "Kurgan Group" Chaltyrsky XI" and Kurgans 2, 3, 4 of the "Kurgan Group "Mokro-Chaltyrsky I" in 2015 in the Myasnikovsky District of the Rostov Region]. Arkhiv OOO ANIB, no. 118.

Anderson-Stojanovic V.R., 1987. The Chronology and Function of Ceramic Unguentaria. American Journal of Archaeology, vol. 91, no. 1, pp. 105-122.

Avram A., 2007. Some Thoughts about the Black Sea and the Slave Trade before the Roman Domination $\left(6^{\text {th }}-\right.$ $1^{\text {st }}$ Centuries BC). The Black Sea in Antiquity: Regional and Interregional Exchanges. Aarhus, Aarhus University Press, pp. 239-251.

Bouchon R., Kyriakidis N., 2017. La prêtrise d'Apollon Pythien à Delphes, observatoire desdynamiques sociales dans la Grèce sous domination romaine (IIe. s. av. J.-C. - IIe s. apr. J.-C.). Social dynamics under Roman rule. Mobility and status change in the provinces of Achaia and Macedonia. Meletemata 74, pp. 211-240.

Garlan Y., 2004. Les timbres céramiques sinopéens sur amphores et sur tuiles trouvés à Sinope. Présentation et catalogue. Avec la collaboration de H. Kara. Varia Anatolica XVI, Corpus international des timbres amphoriques 10. Paris, Institut français détudes anatoliennes Georges Dumézil, De Boccard. 310 p.

Daux G., 1943. Chronologie delphique (supplément au tome III des Fouilles de Delphes). Paris, E. de Boccard. $131 \mathrm{p}$.

Finkielsztejn G., 2001. Chronologie detaillee et revisee des eponyms amphoriques rhodiens de 270 a 108 av. J.-C. environ. Premier bilan. BAR International Series 990. Oxford, Archaeopress. 260 p.

Mulliez D., 1998. La chronologie de la prêtrise IV (170/69-158/7) et la date de la mort d'Eumène II. Topoi, vol. 8/1, pp. 231-241.

Mulliez D., 2006. Les fils d'Ariane: quelques questions de chronologie delphique. Comptes rendus des séances de l'Académie des Inscriptions et Belles-Lettres, $150^{\circledR}$ année, no. 4, pp. 2233-2255.

Rotroff S.I., 1997. Hellenistic Pottery: Athenian and Imported Wheelmade Tableware. The Athenian Agora, vol. XXIX, part 2: Illustrations. Princeton, American School of Classical Studies at Athens. 612 p.

Walbank F.W., 1979. A Historical Commentary on Polybius. Vol. III: Commentary on Books XIX-XL. Oxford, The Clarendon Press. XXI +834 p. 


\section{Information About the Authors}

Vyacheslav P. Glebov, Candidate of Sciences (History), Researcher, OOO Archaeological Research Bureau, Ul'yanovskaya St, 50, 344002 Rostov-on-Don, Russian Federation, glebov-63@mail.ru, https://orcid.org/0000-0002-9692-4616

Anton V. Dedyulkin, Assistant, Department of Archaeology and History of the Ancient World, Southern Federal University, Bolshaya Sadovaya St, 33/43, 344082 Rostov-on-Don, Russian Federation, donrumata@inbox.ru, https://orcid.org/0000-0003-0100-8007

\section{Информация об авторах}

Вячеслав Петрович Глебов, кандидат исторических наук, научный сотрудник, Археологическое научно-исследовательское бюро, ул. Ульяновская, 50, 344002 г. Ростов-на-Дону, Российская Федерация, glebov-63@mail.ru, https://orcid.org/0000-0002-9692-4616

Антон Владимирович Дедюлькин, ассистент кафедры археологии и истории древнего мира, Южный федеральный университет, ул. Большая Садовая, 33/43, 344082 г. Ростов-на-Дону, Российская Федерация, donrumata@inbox.ru, https://orcid.org/0000-0003-0100-8007 